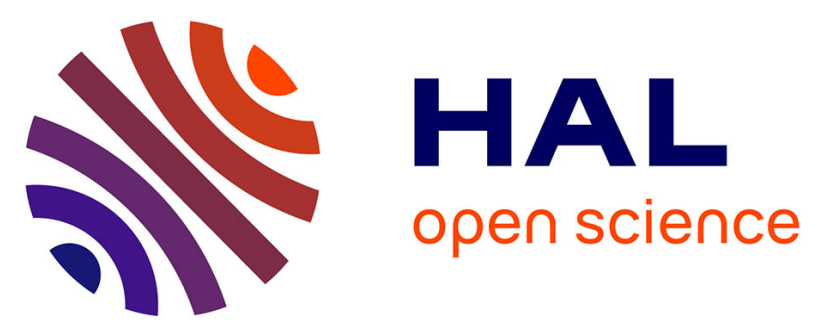

\title{
Structure-property relationships of common aluminum weld alloys utilized as feedstock for GMAW-based 3-D metal printing
}

\author{
Amberlee S Haselhuhn, Michael W Buhr, Bas Wijnen, Paul G Sanders, \\ Joshua Pearce
}

\section{To cite this version:}

Amberlee S Haselhuhn, Michael W Buhr, Bas Wijnen, Paul G Sanders, Joshua Pearce. Structureproperty relationships of common aluminum weld alloys utilized as feedstock for GMAWbased 3-D metal printing. Materials Science and Engineering: A, 2016, 673, pp.511-523. 10.1016/j.msea.2016.07.099 . hal-02113496

\section{HAL Id: hal-02113496 \\ https://hal.science/hal-02113496}

Submitted on 28 Apr 2019

HAL is a multi-disciplinary open access archive for the deposit and dissemination of scientific research documents, whether they are published or not. The documents may come from teaching and research institutions in France or abroad, or from public or private research centers.
L'archive ouverte pluridisciplinaire HAL, est destinée au dépôt et à la diffusion de documents scientifiques de niveau recherche, publiés ou non, émanant des établissements d'enseignement et de recherche français ou étrangers, des laboratoires publics ou privés. 
Pre-print: Amberlee S. Haselhuhn, Michael W. Buhr, Bas Wijnen, Paul G. Sanders, Joshua M. Pearce, StructureProperty Relationships of Common Aluminum Weld Alloys Utilized as Feedstock for GMAW-based 3-D Metal

Printing. Materials Science and Engineering: A, doi:10.1016/j.msea.2016.07.099 (in press, 2016)

\title{
STRUCTURE-PROPERTY RELATIONSHIPS OF COMMON ALUMINUM WELD
} ALLOYS UTILIZED AS FEEDSTOCK FOR GMAW-BASED 3-D METAL PRINTING

\author{
Amberlee S. Haselhuhn, Michael W. Buhr, Bas Wijnen, Paul G. Sanders, Joshua M. Pearce
}

\begin{abstract}
The relationship between microstructure and properties is not widely assessed in parts produced by additive manufacturing, particularly for aluminum. These relationships can be used by engineers to develop new materials, additive processes, and additively manufactured parts for a variety of applications. Thus, the tensile, compressive, and microstructural properties of common aluminum weld filler alloys (ER1100, ER4043, ER4943, ER4047, and ER5356) were evaluated following gas metal arc weld (GMAW)-based metal 3-D printing to identify optimal alloy systems for this type of additive manufacturing. The porosities in all test specimens were found to be less than $2 \%$, with interdendritic shrinkage in 4000 series alloys vs. intergranular shrinkage in 5356. The 4000 series alloys performed better than 1100 and 5356 with respect to printed bead width, porosity, strength, and defect sensitivity. In comparison to standard wrought and weld alloys, the 3-D printed specimens exhibited similar or superior mechanical properties with only minor exceptions. Long print times allow for stress relieving and annealing that improved the print properties of the 4000 series and 5356 alloys. Overall the GMAW-based 3-D parts printed from aluminum alloys exhibited similar mechanical properties to those fabricated using more conventional processing techniques.
\end{abstract}

\section{Introduction}


Pre-print: Amberlee S. Haselhuhn, Michael W. Buhr, Bas Wijnen, Paul G. Sanders, Joshua M. Pearce, StructureProperty Relationships of Common Aluminum Weld Alloys Utilized as Feedstock for GMAW-based 3-D Metal

Printing. Materials Science and Engineering: A, doi:10.1016/j.msea.2016.07.099 (in press, 2016)

3-D printing, a type of additive manufacturing, has technically matured, creating rapid growth in applications such as design and prototyping, small-batch production, and distributed manufacturing ${ }^{1,2,3} .3-\mathrm{D}$ printing can be used to fabricate functional components digitally from a computer model that is then sliced into discrete layers and converted into tool paths for the print head. Parts with varying size and complexity can be printed via 3-D printing for a variety of uses such as open source appropriate technologies (OSAT) for sustainable development ${ }^{4,5}$, patterns for cast metal parts ${ }^{6}$, fuel nozzles for airplane jet engines ${ }^{6}$, consumer products ${ }^{3}$, scientific equipment $^{7,8}$, and prototypes for tools and machine inserts ${ }^{6,7,8}$.

3-D printing is commonly used with polymers due to lower capital costs of the equipment, especially with the arrival of open-source self-replicating rapid prototyper (RepRap) 3-D printer designs ${ }^{9,10,11}$. Metal 3-D printing methods are used industrially and include laser sintering and melting ${ }^{12,13,14,15}$ and electron beam melting ${ }^{16,17,18}$. These industrial-grade additive manufacturing machines can be prohibitively expensive; they generally cost more than US\$500,000 and some metal laser sintering machines can cost upwards of US\$1.5 million, beyond the reach of consumers and small and medium sized enterprises (SMEs) ${ }^{19}$.

Ribeiro (1998) proposed that metal 3-D printing might be accomplished with industrial robots and welding machines, but very little development in this area took place until recently ${ }^{20}$. By augmenting a RepRap 3-D printer design meant for plastic parts, a low-cost metal 3-D printer utilizing gas metal arc welding (GMAW) technology was developed by Anzalone, et al. ${ }^{21}$, and further developed by Haselhuhn, et al. ${ }^{22}$, which enables SMEs and even individuals to print 3-D objects in metal. This system employs a common GMAW welder and is capable of printing steel and aluminum. Initial work to characterize the porosity, hardness, and ultrasonic moduli of parts produced found mechanical properties similar to the bulk wrought material ${ }^{22,23}$. Previously, a 
Pre-print: Amberlee S. Haselhuhn, Michael W. Buhr, Bas Wijnen, Paul G. Sanders, Joshua M. Pearce, StructureProperty Relationships of Common Aluminum Weld Alloys Utilized as Feedstock for GMAW-based 3-D Metal Printing. Materials Science and Engineering: A, doi:10.1016/j.msea.2016.07.099 (in press, 2016)

complete evaluation of mechanical properties has not been reported in the literature for this method of printing. It is important to understand how materials behave when they are 3-D printed as this can guide designs utilizing conventional alloys with GMAW-based metal 3-D printing. This baseline knowledge will also help identify opportunities for improved alloys and processing regimes.

Much of the traditional welding literature can be directly applied to GMAW-based metal 3-D printing to understand fundamental concepts and behaviors of printed metal parts. 3-D printing via GMAW most closely resembles single-layer, multi-pass welding, also known as multi-run welding $24,25,26,27$. This type of welding process reheats previously welded material, thus altering the grain structure, which can improve weld mechanical properties such ductility while reducing residual stress ${ }^{24,25}$. Although GMAW-based metal 3-D printing is analogous to single-layer multi-pass welding technology, 3-D printing with this technology requires special considerations since the weld material comprises the entire part, rather than a small portion ${ }^{26}$. This results in a unique distribution of thermal stresses, microstructures, and mechanical properties as a function of process parameters and part geometry.

Aluminum alloys that are commonly used as weld filler material include ER1100, ER4043, ER4047, and ER5356 (Table 1).

Table 1. Common Aluminum Weld Alloys ${ }^{28,29}$

\begin{tabular}{|c|c|c|}
\hline Alloy & Main Alloying Element & Commonly Used to Join: \\
\hline ER1100 & None; $\geq 99 \% \mathrm{Al}$ & 1xxx series alloys, 3003/3004 Al alloys \\
\hline ER4043 & $4.5-6 \% \mathrm{Si}$ & $\begin{array}{c}\text { 1xxx series alloys, 2xxx series alloys, 3003/3004 Al } \\
\text { alloys, 6xxx series alloys }\end{array}$ \\
\hline ER4943 & 5-6\% Si + 0.3-0.5\% Mg & $\begin{array}{c}\text { 1xxx, 3xxx, 5xxx with less than 3.0\% Mg, and 6xxx } \\
\text { series alloys. }\end{array}$ \\
\hline ER4047 & $11-13 \% \mathrm{Si}$ & 6xxx series alloys \\
\hline ER5356 & $4.5-5.5 \% \mathrm{Mg}$ & 5xxx series alloys, 6xxx series alloys, 7xxx series alloys \\
\hline
\end{tabular}


Pre-print: Amberlee S. Haselhuhn, Michael W. Buhr, Bas Wijnen, Paul G. Sanders, Joshua M. Pearce, StructureProperty Relationships of Common Aluminum Weld Alloys Utilized as Feedstock for GMAW-based 3-D Metal

Printing. Materials Science and Engineering: A, doi:10.1016/j.msea.2016.07.099 (in press, 2016)

ER4943 is a newly developed aluminum welding alloy based from the ER4043 alloy system ${ }^{29}$. Dilution of weld filler materials in the weld is typically anticipated to prevent weld cracking and to produce desired mechanical and electrochemical properties with the exception of ER4943 which was designed to negate the requirement of dilution ${ }^{30}$. However, in GMAW-based metal 3D printing, there is only one material and alloy dilution does not occur. It is important to characterize how common aluminum weld alloys behave in the GMAW-based 3-D printing environment in order to adjust 3-D printing processes on a per-alloy basis, and to guide future alloy development. By printing all materials at the same settings it is straightforward to determine which alloys would benefit from more heat input, faster print speeds, etc.

Heard, et al., analyzed microstructure and fatigue life properties of ER4047 specimens produced via GMAW-based 3-D printing ${ }^{31}$. They observed dendrite arm spacing of 3.5 $\mu \mathrm{m}$ in the first layer which coarsened to $6.6 \mu \mathrm{m}$ in the fourth layer as heat accumulated in the print substrate. Heart, et al., also observed flexural strengths of 3-D printed samples comparable to their cast counterparts. This paper compares to the work of Heard, et al., and extends it to additional aluminum alloys, ER1100, ER4043, ER4943, and ER5356, and evaluates the structure-properties relationships associated with GMAW-based metal 3-D printing of aluminum. In order to understand and design for thermodynamic environment and resulting material properties that arise in the unique welding environment associated with GMAW-based metal 3-D printing, this study evaluates specimen mechanical properties in both compression and tension and also with respect to different print orientations. Microstructural analysis, such as dendrite arm spacing analysis, was also performed on the printed specimens and the fracture surfaces were evaluated. Additional testing, including print resolution, porosity, and ultrasonic 
Pre-print: Amberlee S. Haselhuhn, Michael W. Buhr, Bas Wijnen, Paul G. Sanders, Joshua M. Pearce, StructureProperty Relationships of Common Aluminum Weld Alloys Utilized as Feedstock for GMAW-based 3-D Metal Printing. Materials Science and Engineering: A, doi:10.1016/j.msea.2016.07.099 (in press, 2016)

modulus were included in this study to develop more baseline data for 3-D printed aluminum properties.

\section{Materials and Methods}

Description of the 3D Metal Printer

The open-source GMAW-based metal 3-D printer and software tool chain utilized in this study have been described previously ${ }^{32}$. A Millermatic 190 GMAW welder with a Miller Spoolmate 100 weld gun were used to supply the weld power and the weld material. G-Code to control the 3-D printer was written manually and uploaded to a custom web server that directly interfaced with the printer ${ }^{22,33}$. Standard weld-grade argon cover gas (99.995\% purity) was used during printing. Voltage and current were monitored during printing using custom equipment ${ }^{34}$; the weld power monitor measured voltage and current synchronously, providing signals that were processed and recorded by the robot's firmware.

\section{Printing of Test Specimens}

Standard ER1100 and ER4047 wire (AlcoTec) in addition to ER4043, ER4943, and ER5356 wire (Hobart), 0.035 inches $(0.889 \mathrm{~mm})$ in diameter were used as feedstock material to 3-D print rectangular blocks (105.6 x 26.4 × $25.4 \mathrm{~mm})$ onto cleaned and degreased ASTM A36 steel substrates $(127 \times 127 \times 6.35 \mathrm{~mm})$ (Table 2$)$. Wire compositions were obtained directly from their respective suppliers $35,36,37,38,39$. Aluminum was printed onto low carbon steel as this was previously found to allow easy sample removal ${ }^{22,23}$. 
Pre-print: Amberlee S. Haselhuhn, Michael W. Buhr, Bas Wijnen, Paul G. Sanders, Joshua M. Pearce, StructureProperty Relationships of Common Aluminum Weld Alloys Utilized as Feedstock for GMAW-based 3-D Metal Printing. Materials Science and Engineering: A, doi:10.1016/j.msea.2016.07.099 (in press, 2016)

Table 2. Compositions of Aluminum Weld Wire (wt\%; Single values are maximum values unless otherwise noted)

\begin{tabular}{|c|c|c|c|c|c|c|c|c|c|c|c|}
\hline & & & & & & & & & & \multicolumn{2}{|c|}{ Others } \\
\hline Alloy & Si & $\mathbf{F e}$ & $\mathbf{C u}$ & Mn & Mg & $\mathrm{Cr}$ & Zn & $\mathbf{T i}$ & Be & Each & Total \\
\hline ER1100 & \multicolumn{2}{|c|}{0.95} & $\begin{array}{c}0.05- \\
0.20\end{array}$ & 0.05 & - & - & 0.10 & - & - & 0.05 & 0.15 \\
\hline ER4043 36 & $\begin{array}{c}4.5- \\
6.0\end{array}$ & 0.8 & 0.30 & 0.05 & 0.05 & - & 0.10 & 0.20 & $<0.0003$ & 0.05 & 0.15 \\
\hline ER4943 ${ }^{37}$ & $\begin{array}{c}5.0- \\
6.0 \\
\end{array}$ & 0.40 & 0.10 & 0.05 & $\begin{array}{c}0.30- \\
0.50 \\
\end{array}$ & - & 0.10 & 0.15 & $<0.0003$ & 0.05 & 0.15 \\
\hline $\mathrm{ER} 4047^{38}$ & $\begin{array}{c}11.0 \\
13.0\end{array}$ & 0.8 & 0.30 & 0.15 & 0.10 & - & 0.20 & - & 0.0003 & 0.05 & 0.15 \\
\hline ER5356 39 & 0.25 & 0.40 & 0.10 & $\begin{array}{c}0.05- \\
0.20 \\
\end{array}$ & $\begin{array}{c}4.5- \\
5.5 \\
\end{array}$ & $\begin{array}{c}0.05- \\
0.20 \\
\end{array}$ & 0.10 & $\begin{array}{c}0.06- \\
0.20 \\
\end{array}$ & $<0.0003$ & 0.05 & 0.15 \\
\hline
\end{tabular}

The welder and 3-D printer settings are described in Table 3 whereas the print path for each sample is described in Figure 1. Print settings were constant for all print alloys in order to evaluate the behavior of each alloy under identical processing conditions. All specimens were water quenched immediately after printing. Five (5) identical blocks were printed for each alloy.

Table 3. 3-D Printing Parameters

\begin{tabular}{|c|c|}
\hline Parameter & Value \\
\hline Welder Power Setting (unitless) & 1 \\
\hline Wire Feed Rate (mm/sec) & 124.6 \\
\hline Print Speed (mm/sec) & 10 \\
\hline Wire Stick-Out (mm) & 10 \\
\hline Shield Gas Flow Rate (L/sec) & 0.24 \\
\hline G-Code Layer Height (mm) & 2.5 \\
\hline G-Code Lateral Bead Spacing (mm) & 3.3 \\
\hline Pause After Each Layer (sec) & 60 \\
\hline Number of Print Layers & 15 \\
\hline
\end{tabular}


Odd Layers:

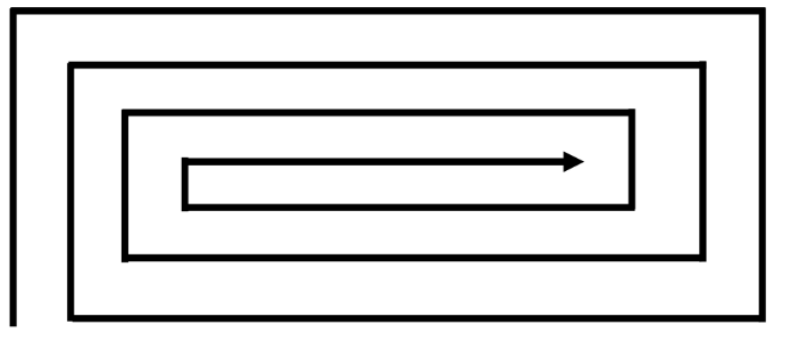

Even Layers:

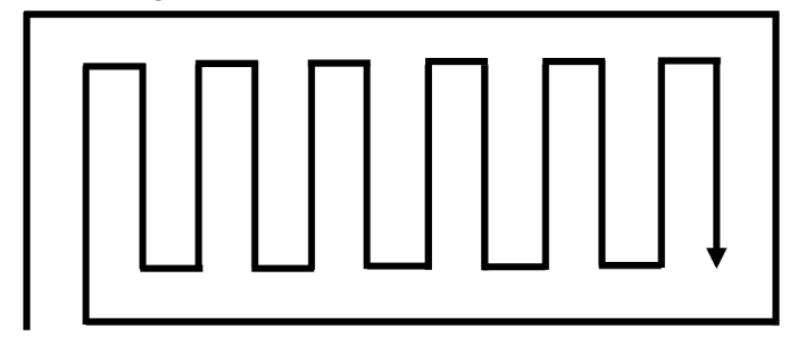

Figure 1. Alternating print paths for all specimens viewed in the direction of the z-axis

Specimen Machining and Analysis

Prior to machining, dimensions of test specimens and bulk porosities were measured. The average center bead width in the top print layer was measured in each alloy using Mitutoyo digital calipers with a $0.01 \mathrm{~mm}$ measurement resolution. This measurement was chosen as it was the most consistent and reliable bead in the top layer of the printed parts, although it did represent a worst-case scenario as the bead widths in the topmost layer would be the largest. Due to topological differences in the print specimens, ten measurements were taken along the entire length of the specimen and averaged. The center bead width provides engineers a metric for print resolution, allowing them to more accurately design 3-D printed components. Internal (closed) porosity in all mechanical test specimens was measured in water according to the Archimedes' principle as described in a previous study ${ }^{23}$.

Using a lathe, four blocks of each alloy were machined into standard round tensile bars (6.35 mm gauge diameter by $25 \mathrm{~mm}$ gauge length) according to ASTM B557 ${ }^{40}$. Each block was machined into 4 tensile bars. One block of each alloy was machined into compression samples and a specimen for microstructural analysis using a 21/2 axis CNC mill (Figure 2). 


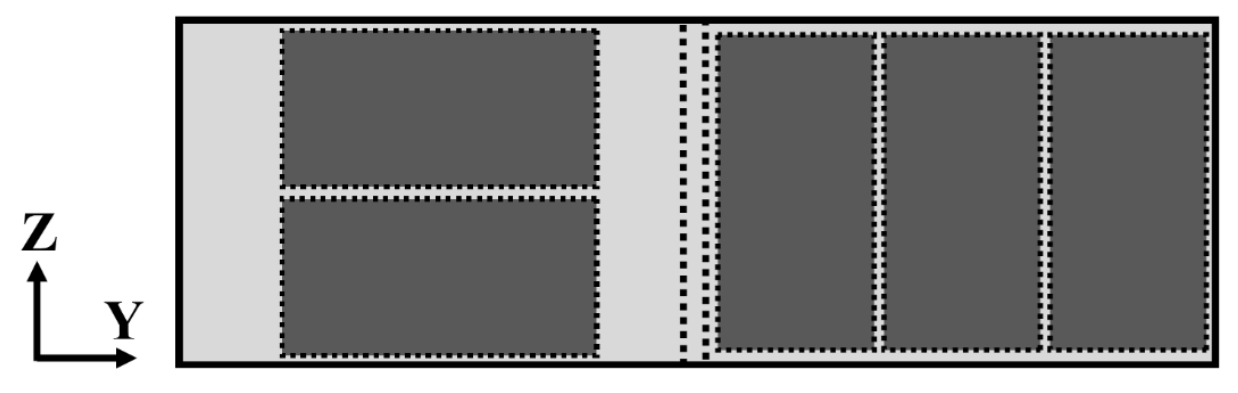

Figure 2. Orientation of compression and microstructural specimen machining

Two compression rectangular solids were oriented parallel and three compression rectangular solids were oriented perpendicular to the print layer to evaluate any anisotropy. The $12.5 x 12.5 x$ $19 \mathrm{~mm}$ compression specimens had a height to width ratio of 1.5:1. The top and bottom surfaces of the specimens were polished to $0.05 \mu \mathrm{m}$ using silica to reduce friction with the compression platens. Microstructural specimens were polished to $0.05 \mu \mathrm{m}$ silica prior to being etched in Keller's solution for 30 seconds for examination in an optical microscope

Tensile specimens were pulled to failure in an Instron load frame with an MTS control package using a $22 \mathrm{kN}$ load cell at a strain rate of $10^{-3} \mathrm{sec}^{-1}$ according to ASTM B557 $7^{40}$. An Epsilon clip-on axial extensometer with a $25 \mathrm{~mm}$ gauge length was used to measure the elongation of the specimen during tensile loading. Only specimens that broken within the gauge section were used for quantitative and qualitative analysis. Tensile fracture surfaces were analyzed in a JEOL 6400 scanning electron microscope (SEM).

Prior to compression, the ultrasonic modulus of the machined compression specimens was measured using an Olympus 38DL Plus ultrasonic thickness gage. The longitudinal wave velocities were measured using an Olympus M112 transducer (10 MHz frequency, 6 mm transducer diameter) with a glycerin couplant. The shear wave velocities were measured using an 
Pre-print: Amberlee S. Haselhuhn, Michael W. Buhr, Bas Wijnen, Paul G. Sanders, Joshua M. Pearce, StructureProperty Relationships of Common Aluminum Weld Alloys Utilized as Feedstock for GMAW-based 3-D Metal Printing. Materials Science and Engineering: A, doi:10.1016/j.msea.2016.07.099 (in press, 2016)

Olympus V157 transducer (5 MHz frequency, 3 mm transducer diameter) with a shear gel couplant. Longitudinal and shear velocities were measured in two specimen orientations: Vertically from the top of the print to the bottom across many layers and horizontally across few layers. Using the longitudinal and shear velocities, in addition to the density measured via the Archimedes’ principle, Poisson’s ratio, elastic moduli, and shear moduli were calculated for each alloy as described in previous study ${ }^{23}$. Using Poisson’s ratio $(v)$ and elastic modulus (E), the bulk modulus $(\mathrm{K})$ of each alloy was calculated (Equation 1$)^{41}$.

$$
K=\frac{E}{3(1-2 v)}
$$

Following ultrasonic modulus testing, compression specimens were lubricated with graphite powder, preloaded to $44.5 \mathrm{~N}$ to ensure sample positioning, and loaded in an Instron load frame with a $150 \mathrm{kN}$ load cell at a strain rate of $10^{-3} \mathrm{sec}^{-1}$. Specimens were compressed to a maximum of $10 \%$ strain. The compression specimens were not loaded to failure as the load cell capacity was reached.

Low silicon solubility in 4043, 4943, and 4047 enabled cooling rate analysis via measurement of secondary dendrite arm spacing (SDAS) from images obtained using a standard optical microscope. SDAS was measured along the center of the 4043, 4943, and 4047 microstructural specimens using ImageJ software ${ }^{42}$. The SDAS was measured across the length of three or more secondary dendrite arms in an edge-to-edge fashion (Figure 3). 


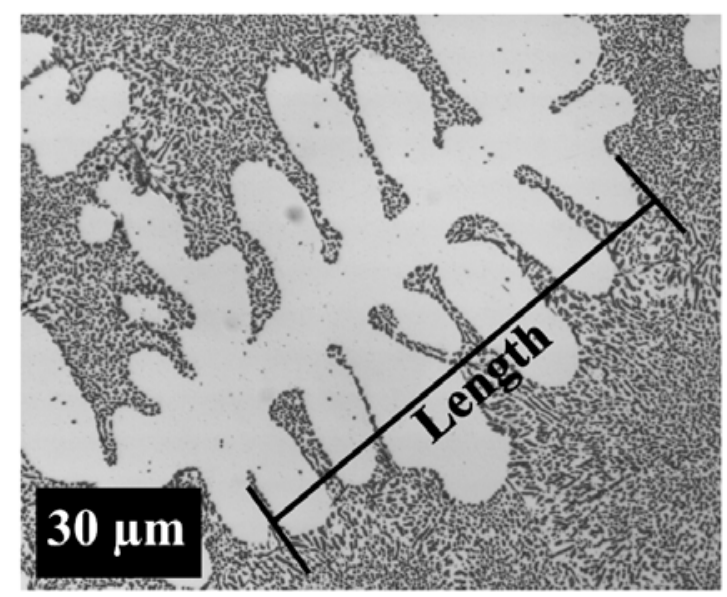

Figure 3. A dendrite in 4047 aluminum, with a schematic line

The SDAS was calculated based upon the total number of secondary dendrite arm spaces (Equation 2) and a characteristic cooling rate was subsequently calculated (Equation 3). L is the length in $\mu \mathrm{m}$ and $\mathrm{N}$ is the number of dendrite arm spaces. The variable $\mathrm{B}$ is a fitting factor for a specific alloy and $\mathrm{n}$ is a constant. For 4043 aluminum, $\mathrm{B}=50 \mu \mathrm{m}\left(\mathrm{Ks}^{-1}\right)^{\mathrm{n}}$ and $\mathrm{n}=0.33$, a unitless number ${ }^{43,44}$. Heard, et al. found agreement between calculated and experimental data when these 4043 aluminum constants were applied to 4047 aluminum $^{31}$. The same computational approach was applied to this study and extended to 4943 aluminum.

$$
\begin{gathered}
S D A S=\frac{L}{N} \\
\text { Cooling Rate }=\left(\frac{S D A S}{B}\right)^{-1 / n}
\end{gathered}
$$

The microstructural specimens were also analyzed in a Philips XL 40 environmental scanning electron microscope. Characterization of an iron gradient within the first two print layers was performed using energy dispersive spectroscopy for an alloy with a large solidification range (4043) and an alloy with a small solidification range (4047). All 
Pre-print: Amberlee S. Haselhuhn, Michael W. Buhr, Bas Wijnen, Paul G. Sanders, Joshua M. Pearce, StructureProperty Relationships of Common Aluminum Weld Alloys Utilized as Feedstock for GMAW-based 3-D Metal

Printing. Materials Science and Engineering: A, doi:10.1016/j.msea.2016.07.099 (in press, 2016)

mathematical data in this study was analyzed using Minitab statistical analysis software. Data was verified to follow a normal distribution.

\section{Results}

\section{As-Printed Dimensions \& Porosity}

The top layer center bead width ranged from approximately 5 to $6.5 \mathrm{~mm}$ (Figure 4). The bead width of 1100 was the smallest followed by the 4047 and 4043 . The two alloys with magnesium additions, 4943 and 5356, exhibited the largest bead widths and were statistically equivalent.

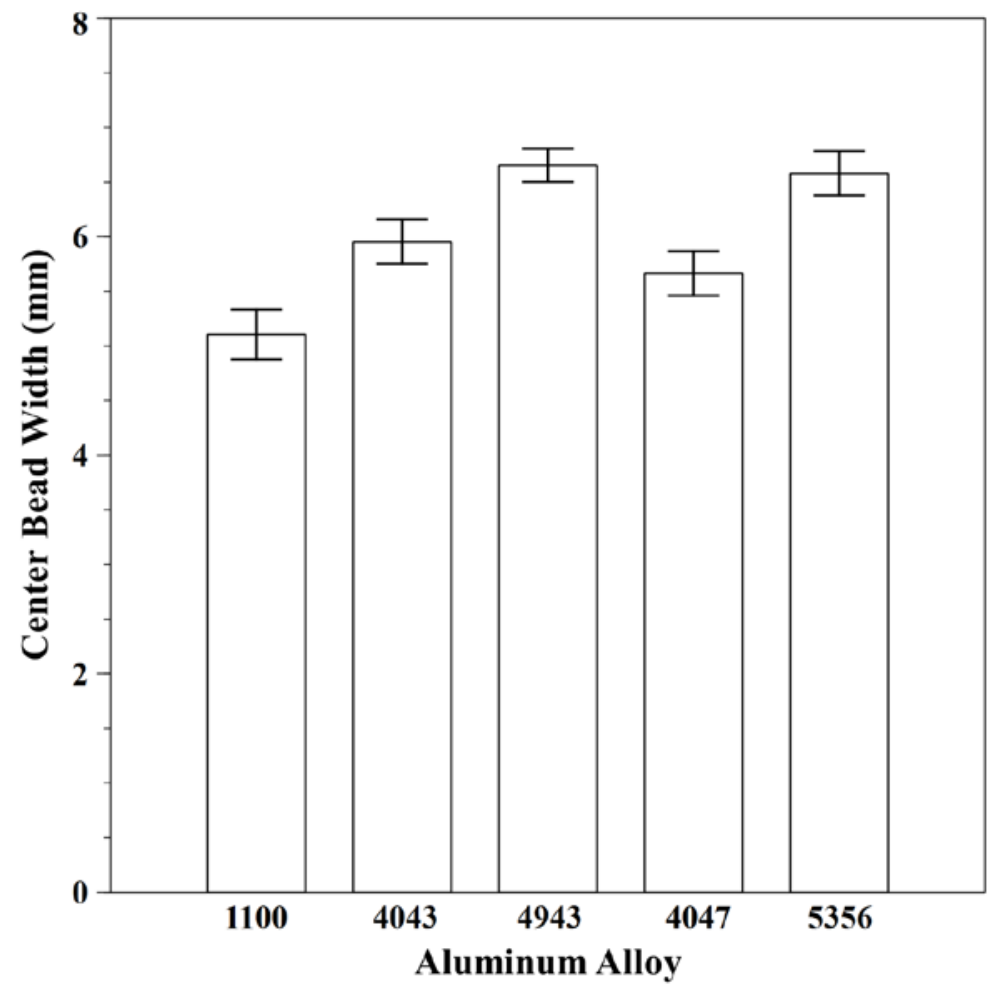

Figure 4. Average center bead width in the top print layer for each aluminum alloy. Error bars represent \pm 2 standard error. 
Pre-print: Amberlee S. Haselhuhn, Michael W. Buhr, Bas Wijnen, Paul G. Sanders, Joshua M. Pearce, StructureProperty Relationships of Common Aluminum Weld Alloys Utilized as Feedstock for GMAW-based 3-D Metal

Printing. Materials Science and Engineering: A, doi:10.1016/j.msea.2016.07.099 (in press, 2016)

Average porosity was generally low and ranged from 0.65 to $1.85 \%$ (Figure 5). The 1100 and 4043 as-printed parts were significantly less porous than the other three aluminum alloys.

The high magnesium 5356 alloy exhibited the greatest porosity.

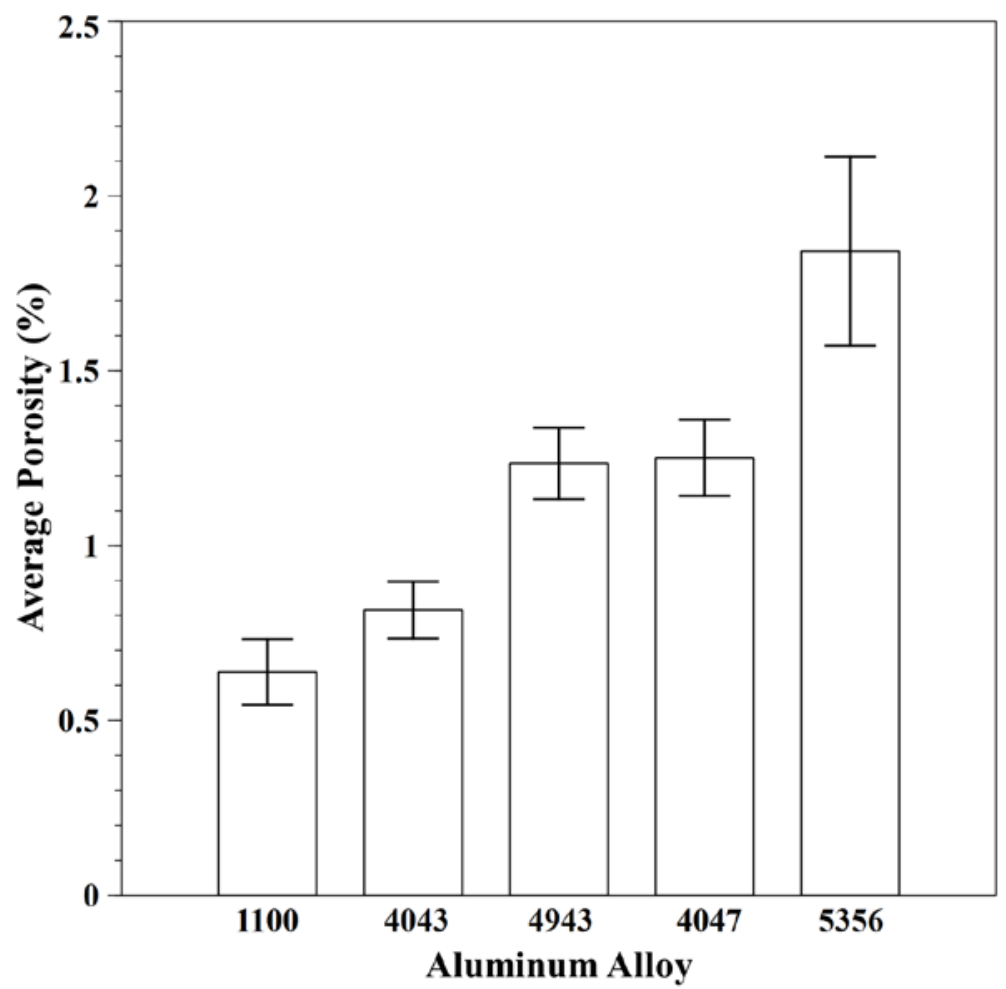

Figure 5. Average porosity of the as-printed specimens. Error bars represent \pm 2 standard error.

Influence of Specimen Location and Orientation on Mechanical Properties

The shear modulus and elastic modulus (Figure 6), the tensile behavior (Figure 7), and the compressive behavior (Figure 8) of each aluminum alloy were evaluated based upon specimen orientation in the printed block. Horizontal elastic modulus, shear modulus, and compression specimens had their long axis in the x-y plane; vertical specimens had their long axis in the z-direction across many layers. In the tensile specimens bottom specimens were closer to the steel print substrate and had more heat flow through them than top specimens. Very minor 
Pre-print: Amberlee S. Haselhuhn, Michael W. Buhr, Bas Wijnen, Paul G. Sanders, Joshua M. Pearce, StructureProperty Relationships of Common Aluminum Weld Alloys Utilized as Feedstock for GMAW-based 3-D Metal Printing. Materials Science and Engineering: A, doi:10.1016/j.msea.2016.07.099 (in press, 2016)

differences in moduli, tensile behavior, or compressive behavior were observed based upon specimen orientation. The 1100 alloy vertical specimens exhibited higher moduli than the horizontal specimens. The only differences in ultimate tensile strength based upon sample location occurred in 1100 and 4047 in which the strengths of the bottom specimens were less than those of the top specimens. In elongation, the bottom specimens of 1100, 4943, and 4047 were all less than the top specimens.
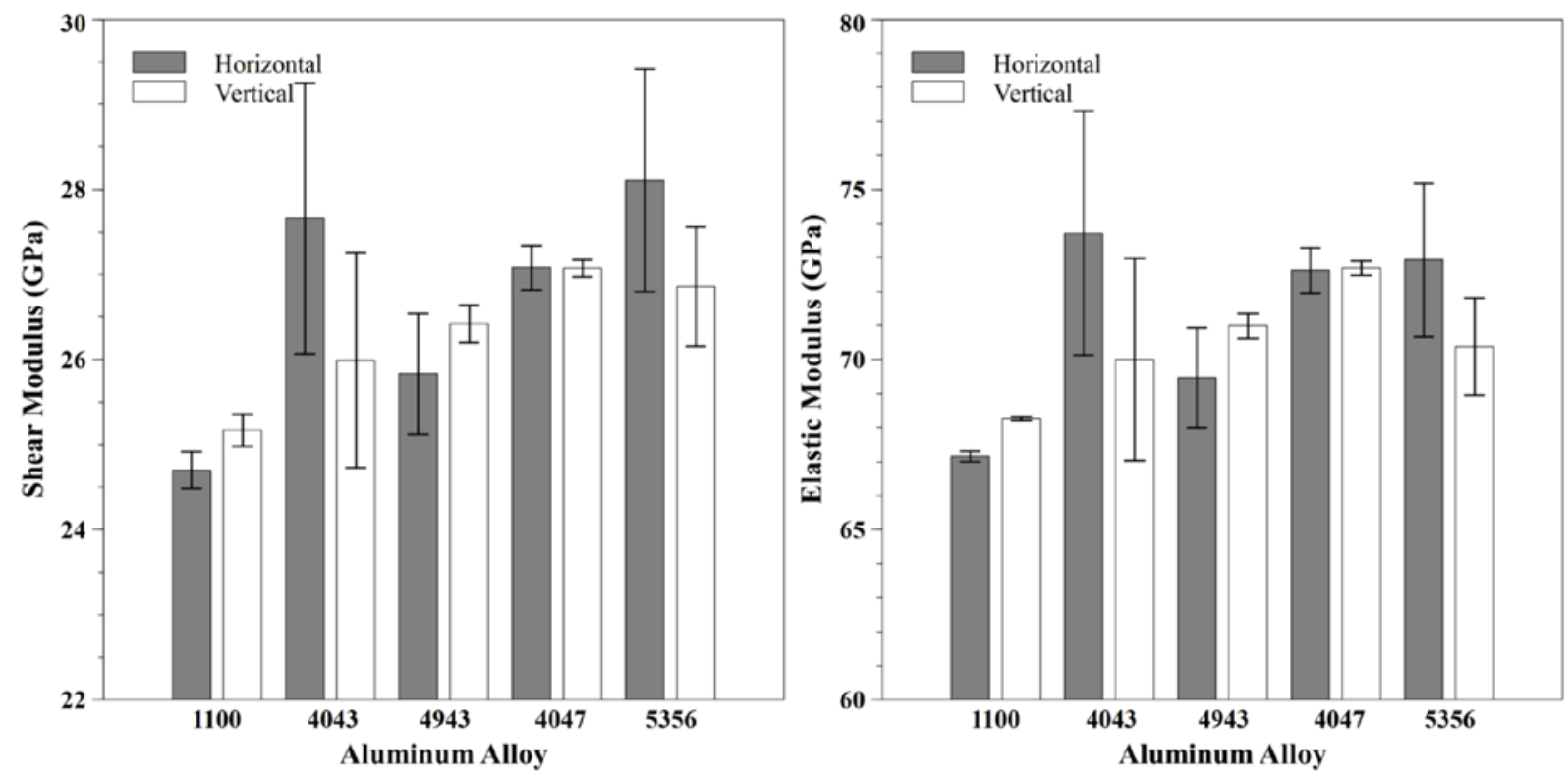

Figure 6. Influence of specimen orientation on the shear modulus (left) and elastic modulus (right) of each aluminum alloy. Error bars represent \pm 2 standard error. 
Pre-print: Amberlee S. Haselhuhn, Michael W. Buhr, Bas Wijnen, Paul G. Sanders, Joshua M. Pearce, StructureProperty Relationships of Common Aluminum Weld Alloys Utilized as Feedstock for GMAW-based 3-D Metal Printing. Materials Science and Engineering: A, doi:10.1016/j.msea.2016.07.099 (in press, 2016)
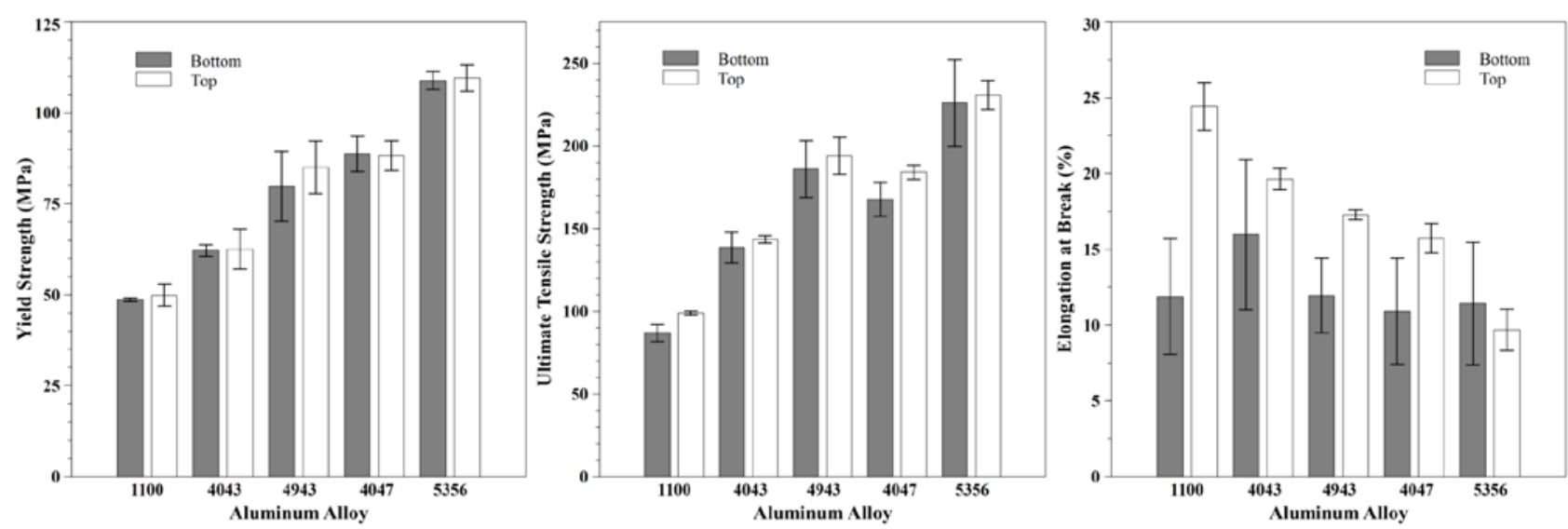

Figure 7. Influence of specimen location in printed block on tensile yield strength (left), ultimate tensile strength (center), and elongation at break (right). Error bars represent \pm 2 standard error.

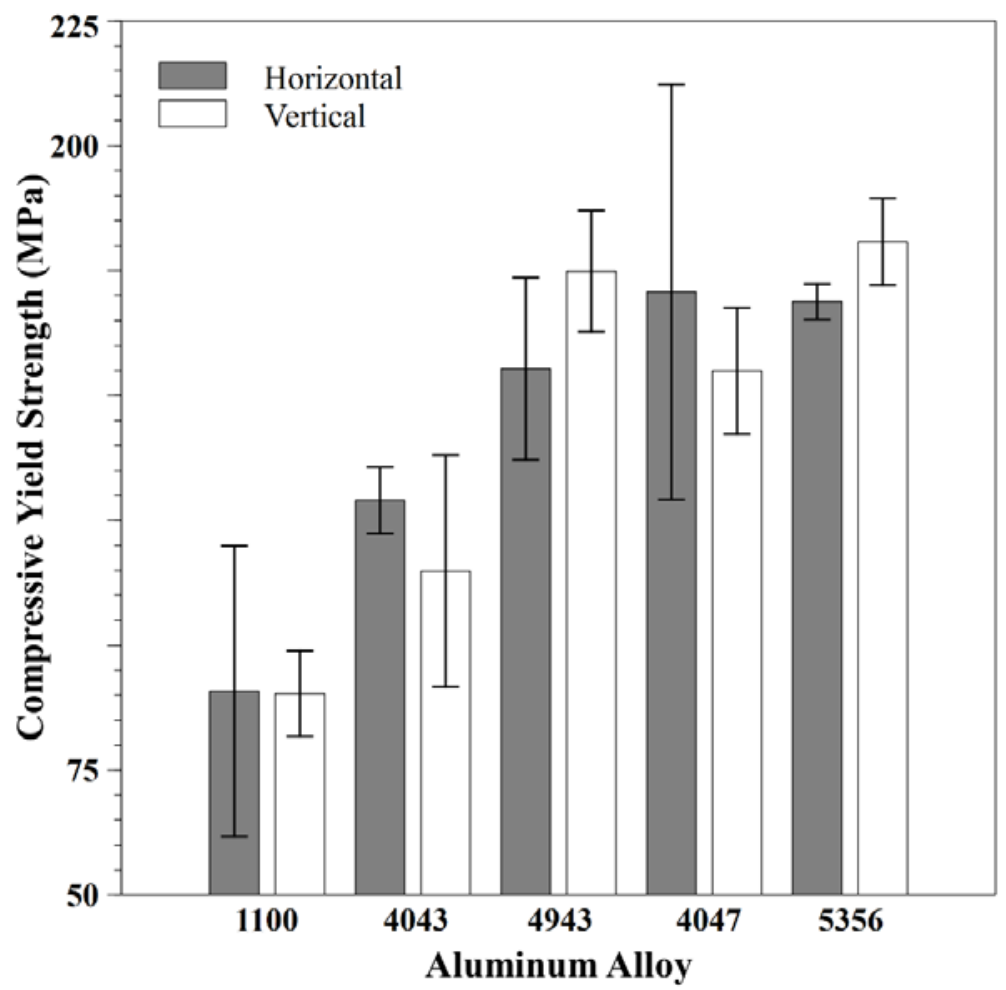

Figure 8. Influence of specimen orientation in printed block on compressive yield strength. Error bars represent \pm 2 standard error. 
Pre-print: Amberlee S. Haselhuhn, Michael W. Buhr, Bas Wijnen, Paul G. Sanders, Joshua M. Pearce, StructureProperty Relationships of Common Aluminum Weld Alloys Utilized as Feedstock for GMAW-based 3-D Metal Printing. Materials Science and Engineering: A, doi:10.1016/j.msea.2016.07.099 (in press, 2016)

Average Mechanical Properties

The shear and elastic moduli of all alloys were greater than those for 1100 (Table 4). The elastic and shear moduli of 4047 were also greater than those observed for 4943 . There was no significant difference in the moduli of 4043 and 4943. Greater variation in the data was observed for 4043 and 5356 specimens. The bulk modulus was largest for 1100 specimens. The lowsilicon 4043 and 4943 specimens exhibited a larger bulk modulus on average than 4047 although this trend was not statistically significant. The 5356 specimens exhibited the smallest bulk modulus.

Table 4. Average calculated elastic properties for each aluminum alloy with \pm 2 standard error

\begin{tabular}{|c|c|c|c|c|}
\hline Alloy & Poisson's Ratio & $\begin{array}{c}\text { Elastic Modulus } \\
\text { (GPa) }\end{array}$ & $\begin{array}{c}\text { Shear Modulus } \\
\text { (GPa) }\end{array}$ & $\begin{array}{c}\text { Bulk Modulus } \\
\text { (GPa) }\end{array}$ \\
\hline 1100 & $0.36 \pm 0.005$ & $67.7 \pm 0.5$ & $25.0 \pm 0.3$ & $77.8 \pm 2.5$ \\
\hline 4043 & $0.34 \pm 0.009$ & $71.5 \pm 2.7$ & $26.7 \pm 1.2$ & $75.0 \pm 1.4$ \\
\hline 4943 & $0.34 \pm 0.005$ & $70.4 \pm 0.9$ & $26.2 \pm 0.4$ & $75.2 \pm 2.1$ \\
\hline 4047 & $0.34 \pm 0.001$ & $72.7 \pm 0.2$ & $27.1 \pm 0.1$ & $76.5 \pm 0.4$ \\
\hline 5356 & $0.31 \pm 0.010$ & $71.4 \pm 1.6$ & $27.4 \pm 0.8$ & $61.2 \pm 1.8$ \\
\hline
\end{tabular}

Tensile specimen fracture surfaces were highly ductile with typical cup-cone surface morphology (Figure 9). Variation in specimen diameters in Figure 8 demonstrate the reduction of area associated with tensile deformation. The 1100 tensile specimens also exhibited macroconing. Some of the 4047 tensile specimens exhibited some regions of brittle fracture while some of the 5356 tensile specimens exhibited cracking along discrete lines, likely corresponding to barriers between print layers. All fracture surfaces also exhibited higher than average bulk 
Pre-print: Amberlee S. Haselhuhn, Michael W. Buhr, Bas Wijnen, Paul G. Sanders, Joshua M. Pearce, StructureProperty Relationships of Common Aluminum Weld Alloys Utilized as Feedstock for GMAW-based 3-D Metal Printing. Materials Science and Engineering: A, doi:10.1016/j.msea.2016.07.099 (in press, 2016)

porosity, likely resulting from material failure at locally weak regions having the highest concentration of defects.

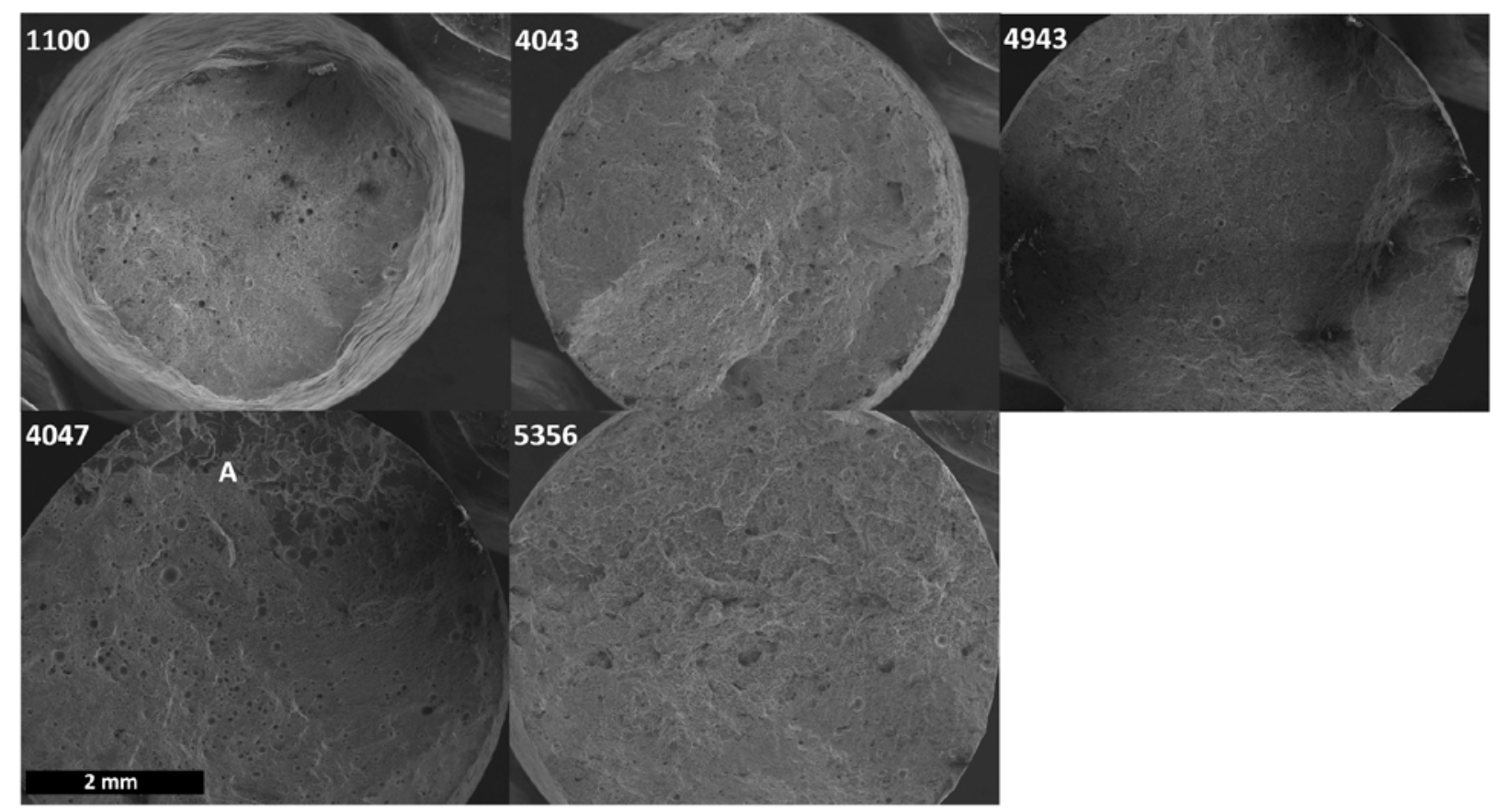

Figure 9. Tensile fracture surfaces of 3-D printed aluminum alloys. Note macro-coning in the 1100 specimen and the region of brittle fracture in 4047 (A). Scale bar represents $2 \mathrm{~mm}$.

Rounded gas porosity was observed in all alloys (Figure 10). In all alloys except 1100, interdendritic or intergranular shrinkage was observed on the fracture surfaces. In these alloys, shrinkage porosity would often be combined with gas-type porosity. 


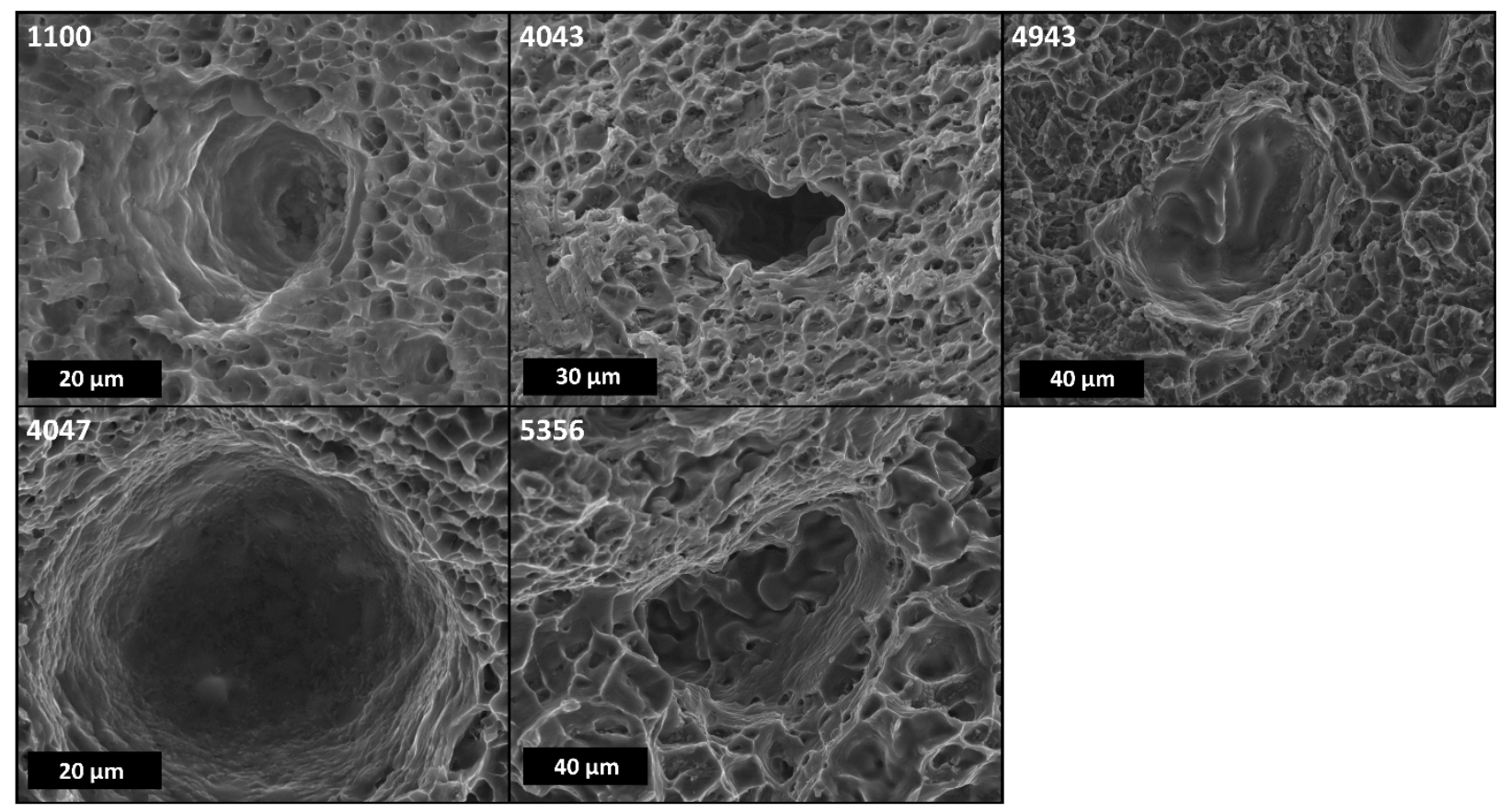

Figure 10. Examples of porosity in each 3-D printed aluminum alloy.

It should be noted that the Figure 10 images were taken of typical poor sizes for each alloy and thus shown at appropriate magnification to make them clear, but they are not all the same size and as can be seen in Figure 9 there are also much larger macro pores. The brittle regions in 4047 also exhibited porosity, although to a lesser extent than the ductile regions (Figure 11). These brittle regions were only observed in some of the tensile specimens machined closest to the print substrate. The brittle fracture regions were marked by transgranular fracture in which aluminum grains were sheared. Element mapping of brittle regions in the 4047 fracture surfaces yielded large features containing primarily silicon with small amounts of iron exhibited as lamellar features. The iron lamellae were only visible in the bottom 1-2 mm of the gauge section. 


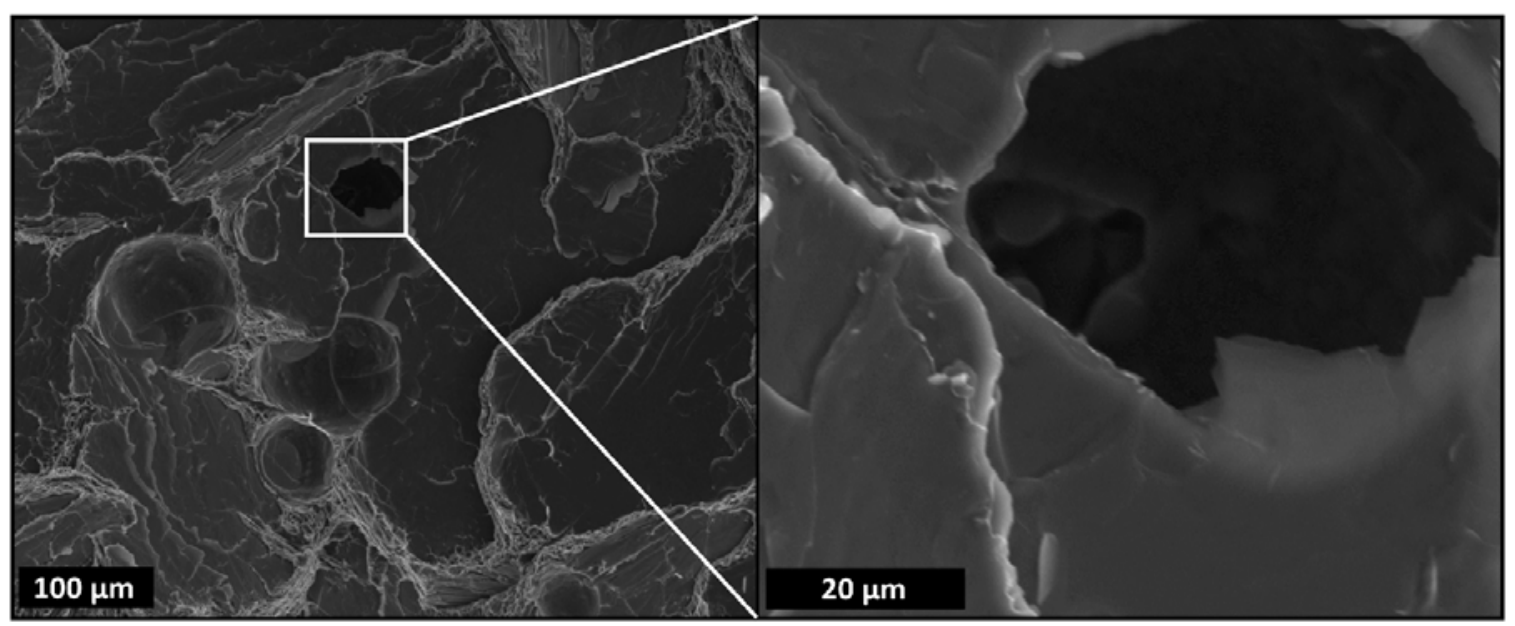

Figure 11. Brittle 4047 fracture surface (left) with porosity (right).

Given than no significant differences were observed with respect to sample location and orientation, all the mechanical measurements were averaged for subsequent analysis.

Additionally, defective 4047 tensile specimens with visible brittle regions were removed from the analysis. The ultimate tensile strengths of the magnesium containing 4943 and 5356 alloys were the highest followed by 4047, 4043, and 1100 (Figure 12). The $2 \%$ offset tensile yield strengths generally followed the same trend except that 4943 fell to the same level as 4047 . Compressive yield strength was significantly higher than tensile yield strength. Compressive and tensile yield strengths followed the similar trends on a per alloy basis. Elongation to failure was generally in the range of 15 to $17 \%$ except for 5356 which was at $10 \%$. The 1100 alloy had the most elongation variation. 
Pre-print: Amberlee S. Haselhuhn, Michael W. Buhr, Bas Wijnen, Paul G. Sanders, Joshua M. Pearce, StructureProperty Relationships of Common Aluminum Weld Alloys Utilized as Feedstock for GMAW-based 3-D Metal Printing. Materials Science and Engineering: A, doi:10.1016/j.msea.2016.07.099 (in press, 2016)
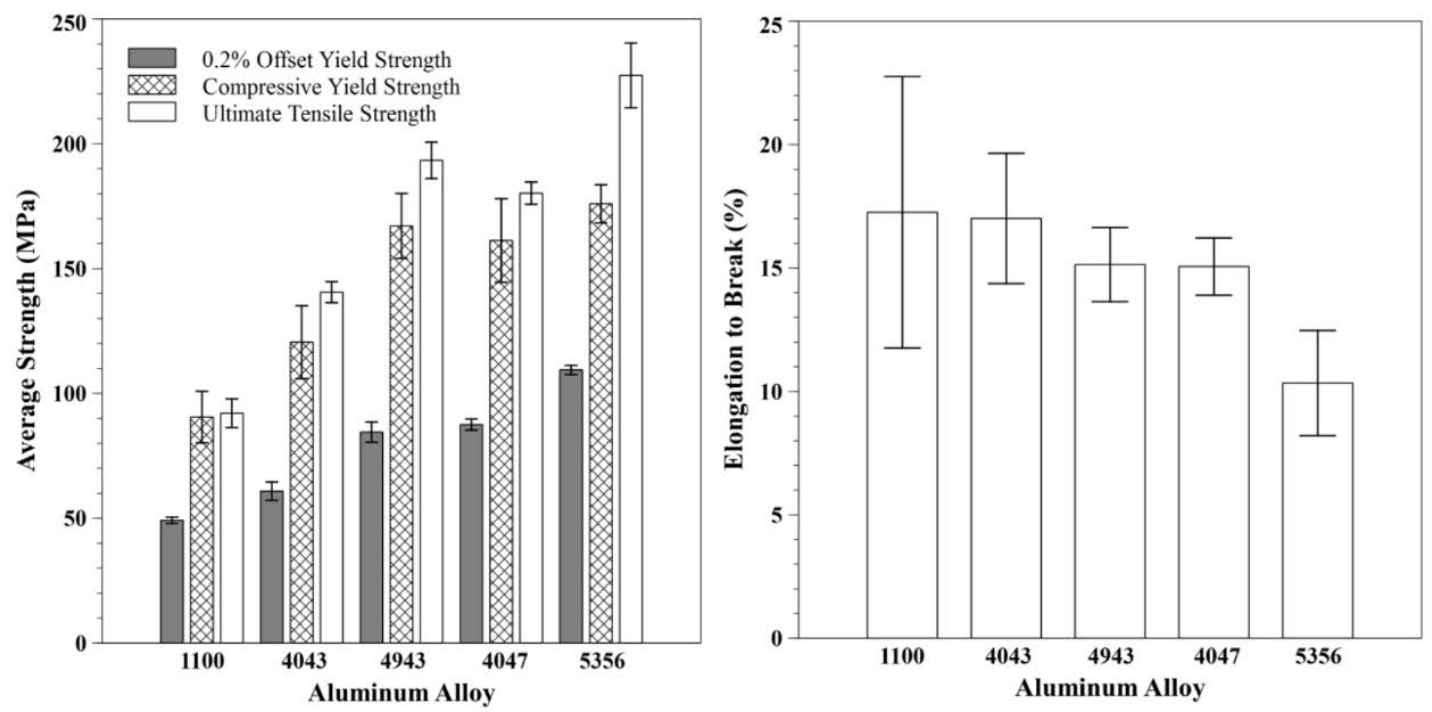

Figure 12. $0.2 \%$ offset yield, compressive yield, and ultimate tensile strengths of the aluminum tensile specimens (left). Elongation at failure of the tensile specimens based upon aluminum alloy type (right). Error bars represent \pm 2 standard error.

\section{Microstructural Analysis}

The single-phase 1100 and 5356 compression specimens exhibited few microstructural features whereas the aluminum and silicon phases were visible in unetched 4043, 4943, and 4047 specimens (Figure 13). The similar Si contents of 4043 and 4943 produced microstructures with comparable amounts of interdendritic dendrites; whereas 4047 had larger areas of eutectic microconstituent. Black features in the "bottom” images may correspond to either hydrogen porosity or regions in which the iron was pulled out of the specimen during polishing procedures. 


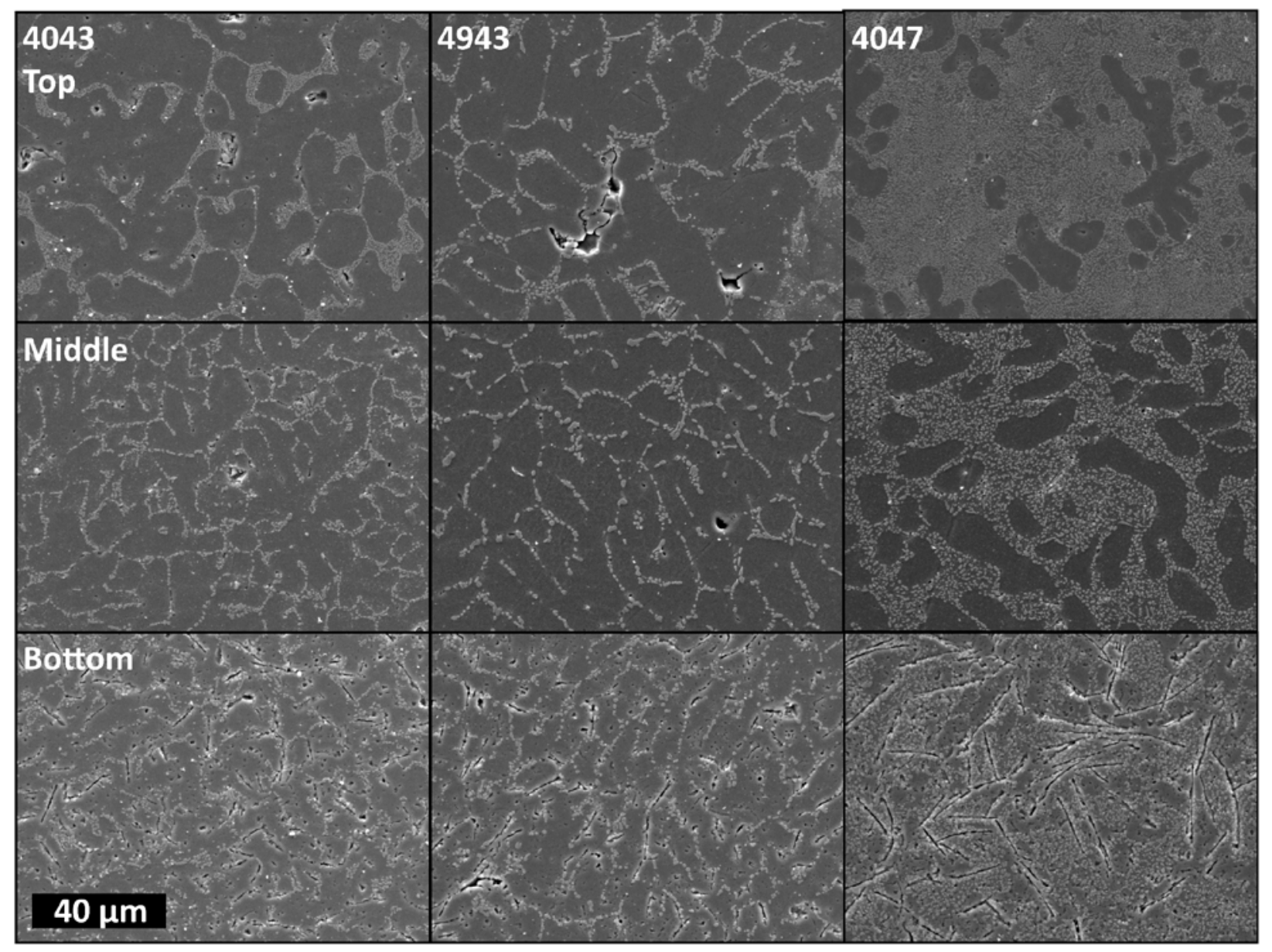

Figure 13. Scanning electron images of 4000 series test specimens in the bottom, top, and middle of the printed block. Scale bar represents $40 \mu \mathrm{m}$.

The secondary dendrite arm spacing (SDAS) of all the 4000 series alloys averaged 8-10 $\mu \mathrm{m}$ (Figure 14). The 4043 and 4047 cross-sections exhibited consistent SDAS with no long range trends within the sample, while the 4943 SDAS increased linearly with distance from the substrate (Equation 4). 
Pre-print: Amberlee S. Haselhuhn, Michael W. Buhr, Bas Wijnen, Paul G. Sanders, Joshua M. Pearce, StructureProperty Relationships of Common Aluminum Weld Alloys Utilized as Feedstock for GMAW-based 3-D Metal

Printing. Materials Science and Engineering: A, doi:10.1016/j.msea.2016.07.099 (in press, 2016)
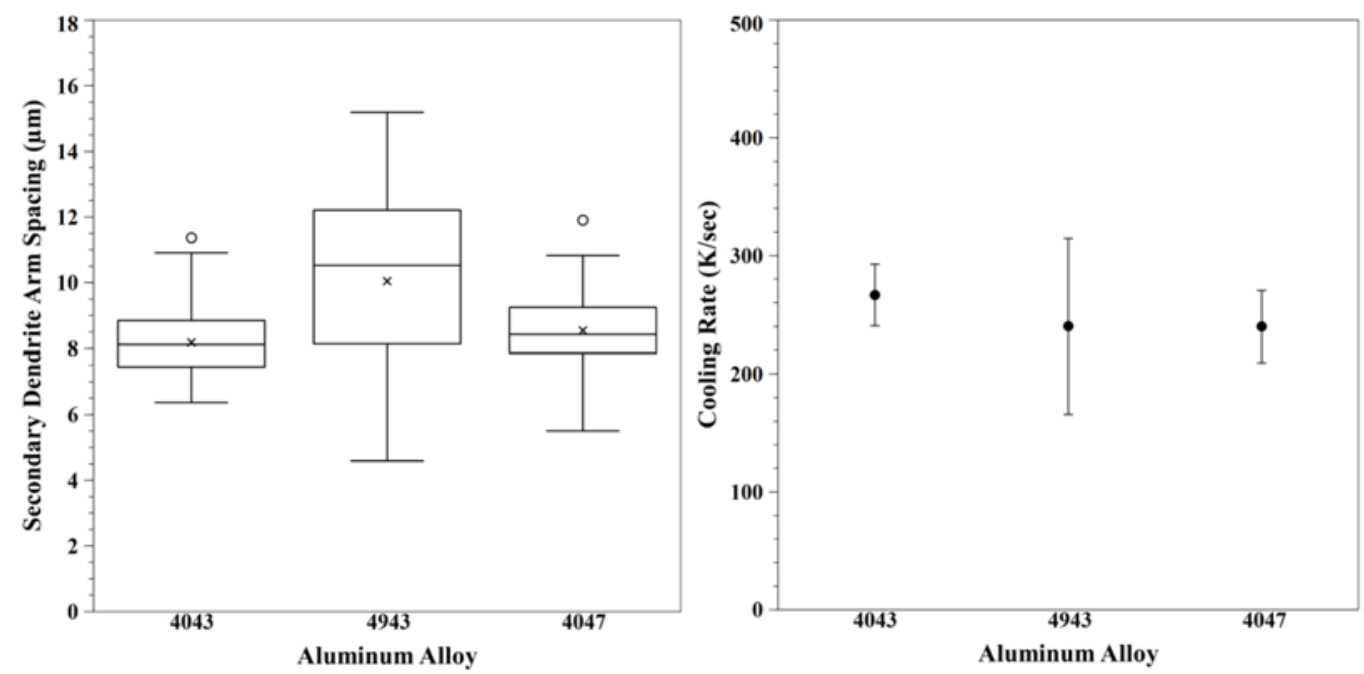

Figure 14. Box plots of 4000 series SDAS (left) and corresponding average cooling rates (right).

Error bars represent \pm 2 standard error.

$$
4943 \operatorname{SDAS}(\mu \mathrm{m})=[0.31 * \text { Distance from substrate }(\mathrm{mm})]+5.72
$$

Iron contamination was observed in the first layer microstructure of each printed alloy (Figure 15), but the iron concentration decreased significantly in the second layer. In the 4000 series specimens, iron contaminants were present as randomly oriented plates. These plates were not visible beyond the first print layer (approximately $3.8 \mathrm{~mm}$ above the print substrate) where the iron content was significantly lower than in the previous portion of the specimen (Figure 16). 
Pre-print: Amberlee S. Haselhuhn, Michael W. Buhr, Bas Wijnen, Paul G. Sanders, Joshua M. Pearce, StructureProperty Relationships of Common Aluminum Weld Alloys Utilized as Feedstock for GMAW-based 3-D Metal Printing. Materials Science and Engineering: A, doi:10.1016/j.msea.2016.07.099 (in press, 2016)

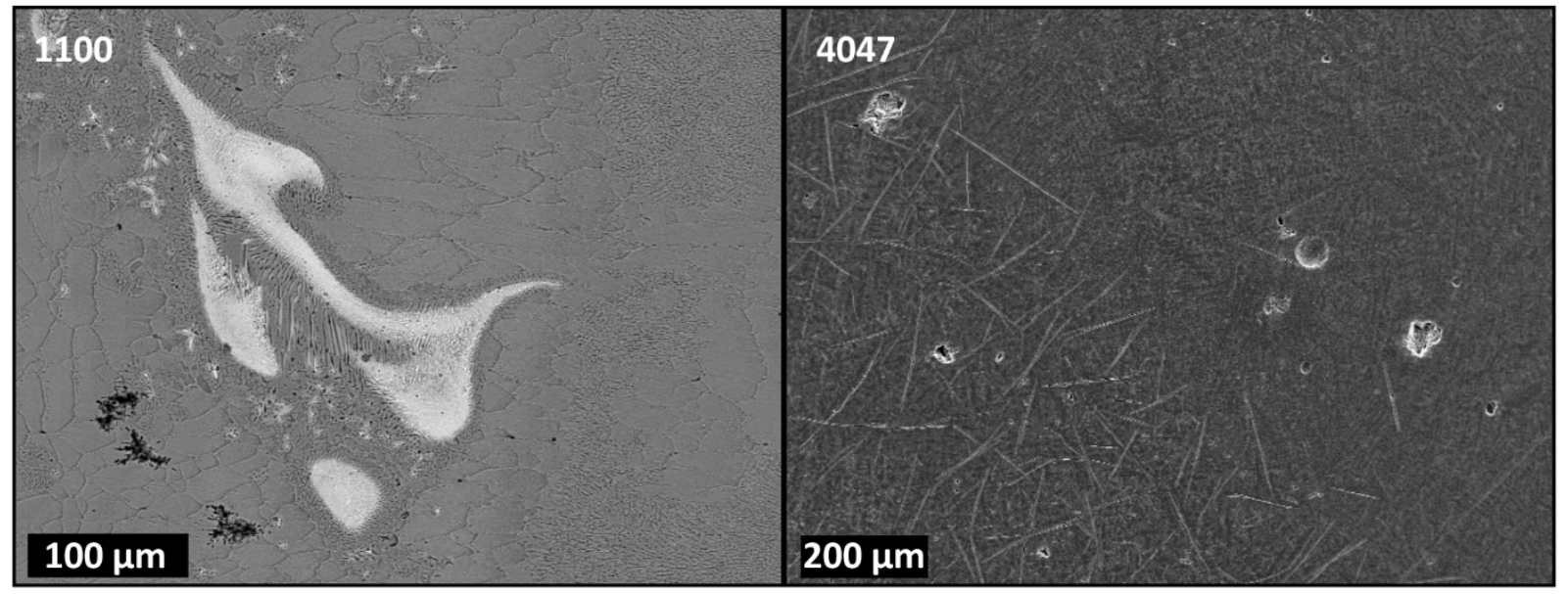

Figure 15. Secondary electron images of iron contamination in the first print layer of 1100 and 4047.

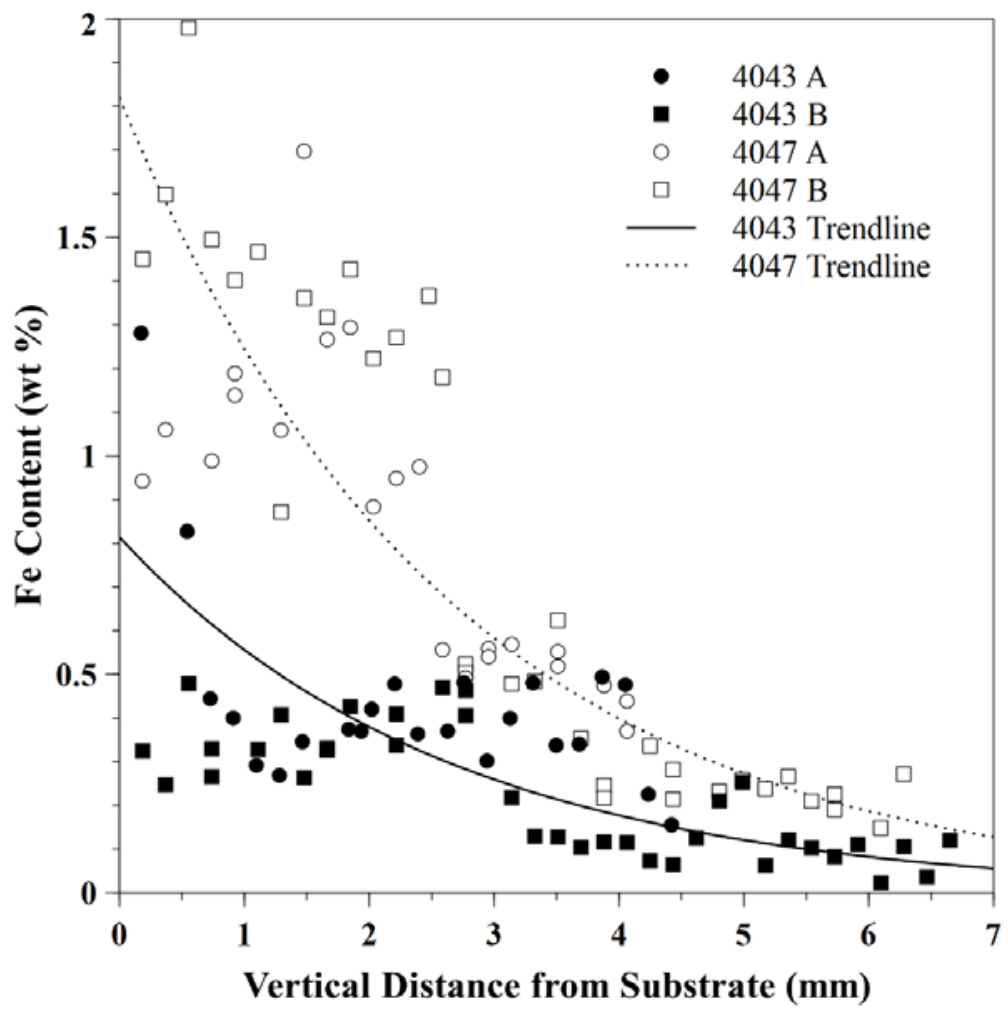

Figure 16. Iron gradient from ESD of the first two print layers of 4043 and 4047. 
Pre-print: Amberlee S. Haselhuhn, Michael W. Buhr, Bas Wijnen, Paul G. Sanders, Joshua M. Pearce, StructureProperty Relationships of Common Aluminum Weld Alloys Utilized as Feedstock for GMAW-based 3-D Metal Printing. Materials Science and Engineering: A, doi:10.1016/j.msea.2016.07.099 (in press, 2016)

The 4047 microstructure in brittle regions of the tensile fracture surface exhibited silicon and iron within the lamellar features (Figure 17) shown previously (Figure 15). Portions of the iron plates were pulled out during the polishing process, leaving behind crack-like formations that appear as voids.

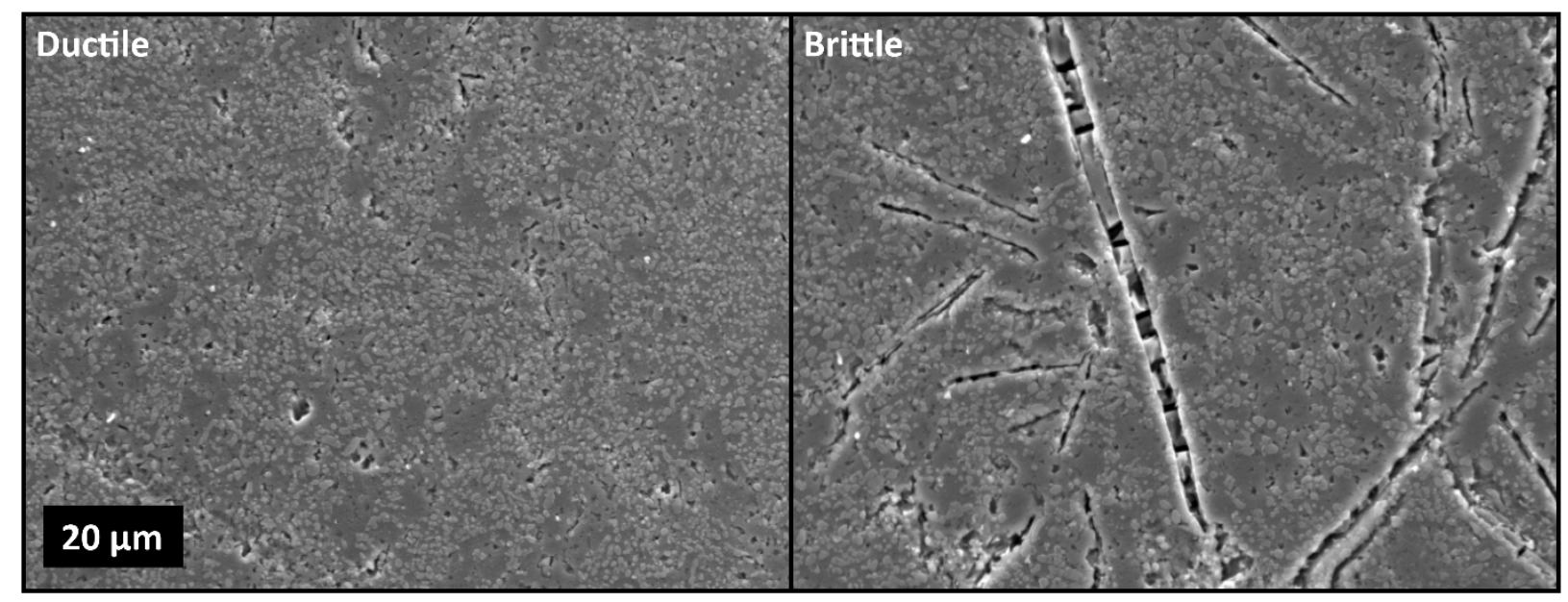

Figure 17. Ductile (left) and brittle (right) microstructures observed in 4047 tensile specimens. Scale bar represents $20 \mu \mathrm{m}$.

\section{Discussion}

\section{As-Printed Dimensions \& Porosity}

At similar cooling rates, one would expect alloys with large freezing ranges to take more time to solidify and thus have the potential to flow into wider beads. Indeed, the commercially pure 1100 aluminum and near-eutectic 4047 exhibited the smallest bead widths while the alloys with magnesium (4943 and 5356) had larger bead widths.

Alloy fluidity aids in feeding interdendritic shrinkage. Improved fluidity is observed with decreasing solidification range and with a decrease in liquid metal viscosity. Both silicon and 
Pre-print: Amberlee S. Haselhuhn, Michael W. Buhr, Bas Wijnen, Paul G. Sanders, Joshua M. Pearce, StructureProperty Relationships of Common Aluminum Weld Alloys Utilized as Feedstock for GMAW-based 3-D Metal Printing. Materials Science and Engineering: A, doi:10.1016/j.msea.2016.07.099 (in press, 2016)

magnesium additions have been shown to decrease the internal friction in molten aluminum alloys, resulting in a decrease in viscosity ${ }^{45}$. Metal fluidity increases as the solidification range decreases such that pure alloys (1100) and near-eutectic alloys (4047) will exhibit less shrinkage porosity than alloys with larger solidification ranges (4043, 4943, and 5356) $)^{\text {Error! Bookmark not }}$ defined. The observed interdendritic shrinkage (Figure 10) is common in aluminum weld structures $^{24}$. Alloys with higher silicon contents such as 4047 have fewer primary aluminum dendrites and are less likely to exhibit interdendritic shrinkage and cracks as interdendritic feeding is able to fill the space between dendrite before the metal is fully solidified ${ }^{46}$. In alloys with more primary aluminum, such as 4043 and 4943, interdendritic feeding is more difficult resulting in interdendritic porosity. Additionally, unlike aluminum, silicon has higher specific and latent heats, and expands as it solidifies; thus, alloys with higher silicon contents suffer less

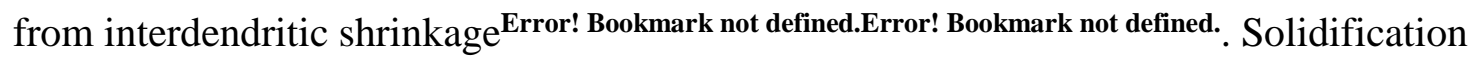
shrinkage can be described as a ratio of an alloy’s solid and liquid densities, $\rho_{\mathrm{s}}$ and $\rho_{\mathrm{l}}$, respectively (Equation 5) ${ }^{47}$.

$$
\text { Shrinkage }=\frac{\rho_{s}-\rho_{l}}{\rho_{s}}
$$

Magnusson and Arnberg observed experimentally that increasing silicon content in hypoeutectic aluminum-silicon alloys increased the alloy's liquid density and simultaneously decreased the solid density, reducing the shrinkage observed in castings ${ }^{47}$. The changes in density were attributed to silicon's ability to expand upon solidification ${ }^{47}$. Magnesium additions in 4943 and 5356 produce larger solidification ranges leading to higher shrinkage porosity.

Weld porosity due to dissolved atmospheric gases such as hydrogen and nitrogen is a well-established phenomenon ${ }^{24,25,46}$. Aluminum has a high affinity for hydrogen, which is less 
Pre-print: Amberlee S. Haselhuhn, Michael W. Buhr, Bas Wijnen, Paul G. Sanders, Joshua M. Pearce, StructureProperty Relationships of Common Aluminum Weld Alloys Utilized as Feedstock for GMAW-based 3-D Metal Printing. Materials Science and Engineering: A, doi:10.1016/j.msea.2016.07.099 (in press, 2016)

soluble in solid metal than in a liquid metal ${ }^{46}$. Upon cooling, this gas comes out of solution and either escapes or, if solidification is sufficiently fast, is trapped to form gas porosity. If reactive magnesium is oxidized, it can increase porosity by serving as heterogeneous nucleation sites for

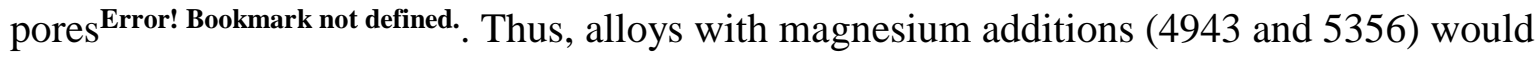
exhibit more nucleation sites for porosity formation.

\section{Influence of Specimen Orientation on Mechanical Properties}

Mechanical properties were not observed to differ significantly based upon specimen location or orientation. The layered structure of the 3-D printed parts did not negatively affect mechanical properties. Elevated iron levels were observed in the first layer of all alloys, up to approximately $4 \mathrm{~mm}$ above the print substrate, which resulted in fibrous iron intermetallics in the first layer (Figure 17). This iron gradient did not extend far enough in the 3-D printed blocks to cause elevated iron content in the gauge section of tensile specimens or in the compression specimens.

Elevated iron content within the first $4 \mathrm{~mm}$ was a result of printing the aluminum test specimens on a steel substrate. To evaluate whether this iron content was the result of solid state diffusion, liquid mixing in the weld pool, or a combination thereof, the theoretical steady state diffusion length of iron in aluminum was calculated (Equation 6) ${ }^{48}$.

$$
\text { Length }=\sqrt{\text { Diffusivity } * \text { time }}
$$

The diffusivity of iron in pure aluminum was reported by Hirano, et al., to be $4.9 * 10^{-9} \exp (-$ $13,900 / \mathrm{RT}) \mathrm{cm}^{2} / \mathrm{sec}^{49}$. Using this information, the diffusion length of iron into aluminum was calculated at the melting temperature of pure aluminum (933 K) and at the eutectic temperature of a hypoeutectic aluminum-silicon alloy (850 K) (Figure 18). 
Pre-print: Amberlee S. Haselhuhn, Michael W. Buhr, Bas Wijnen, Paul G. Sanders, Joshua M. Pearce, StructureProperty Relationships of Common Aluminum Weld Alloys Utilized as Feedstock for GMAW-based 3-D Metal

Printing. Materials Science and Engineering: A, doi:10.1016/j.msea.2016.07.099 (in press, 2016)

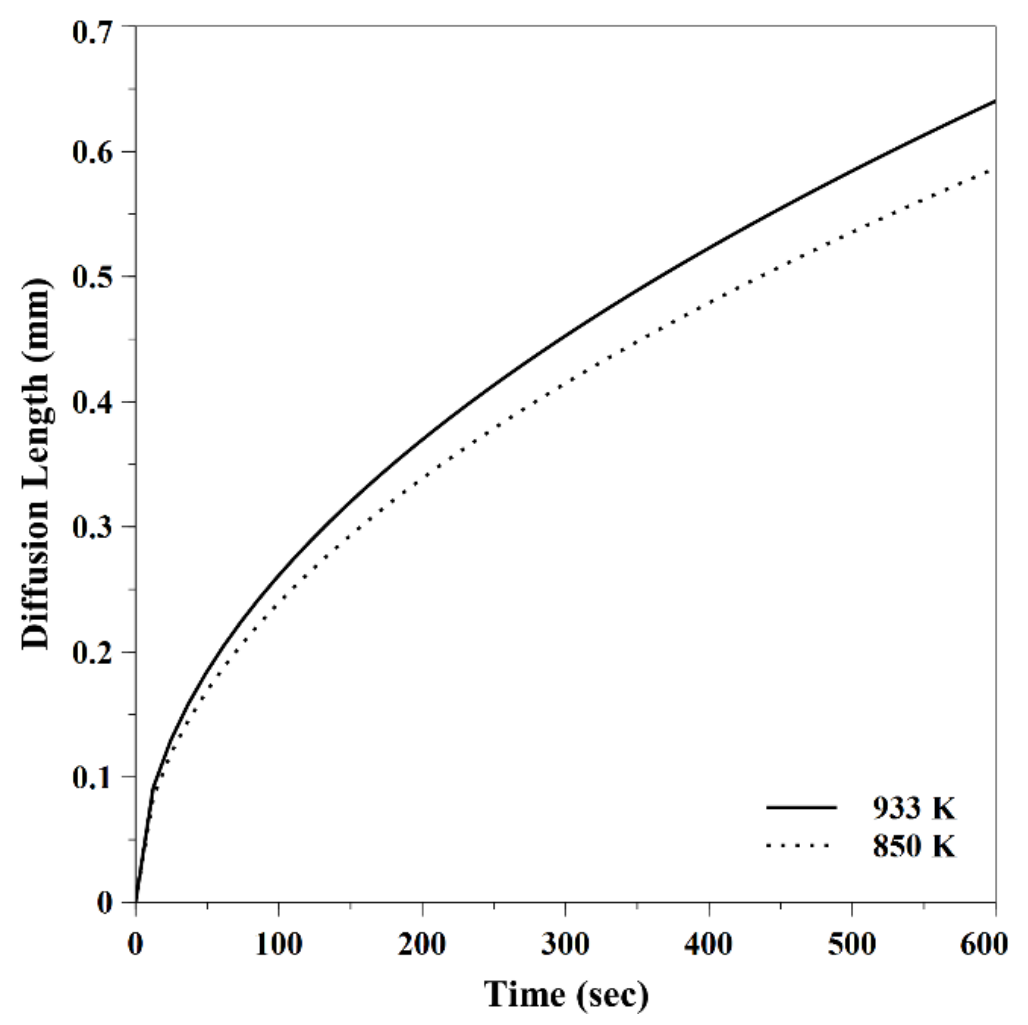

Figure 18. Calculated diffusion length of iron in aluminum as a function of solidification time.

From Figure 18 it was evident that even at long solidification times of 300 or more seconds, the maximum diffusion length of iron in aluminum is less than $1 \mathrm{~mm}$. Thus, solid state diffusion cannot fully account for the iron gradient observed in 3-D printed aluminum parts. Fluid flow within the liquid metal weld pool mixed iron compounds into the first layer of the welded part, resulting in iron contents further into the welded part than could be accounted for by solid state diffusion $^{46}$. In the aluminum-silicon alloys this resulted in lamellar features. These same features were observed in hypoeutectic aluminum-silicon alloyed with iron additions and were determined to be $\mathrm{Al}_{5} \mathrm{FeSi}$ platelets ${ }^{50}$. The use of alternate substrate release mechanisms for larger 
Pre-print: Amberlee S. Haselhuhn, Michael W. Buhr, Bas Wijnen, Paul G. Sanders, Joshua M. Pearce, StructureProperty Relationships of Common Aluminum Weld Alloys Utilized as Feedstock for GMAW-based 3-D Metal Printing. Materials Science and Engineering: A, doi:10.1016/j.msea.2016.07.099 (in press, 2016)

prints, such as alumina or nitride coatings, may eliminate iron contamination when printing aluminum on steel 22,23 .

\section{Microstructural Analysis}

The SDAS in this study were similar to those reported by Heard, et al. who observed an approximately constant SDAS of $5.7 \mu \mathrm{m}$ in four layers of 4047 printed by a GMAW-based 3-D printer with five minute pauses between layers ${ }^{31}$. The 4043 and 4047 specimens in this study had approximately constant SDAS of $8.4 \mu \mathrm{m}$ across 15 print layers. In contrast, the 4943 SDAS averaged $10 \mu \mathrm{m}$ but with an increasing linear trend with vertical distance from the substrate. Weld current and voltage in this study were lower than those used by Heard, et $\mathrm{al}^{31}$. Heat input is directly proportional to voltage and current and inversely proportional to weld speed ${ }^{25}$. Greater heat input results in slower cooling and larger SDAS. A weld speed was not reported by Heard, et al., but a faster speed could produce the smaller SDAS than that observed in this study. Additionally, differences in specimen size and shape could result in different cooling that could explain differences in SDAS. The specimens in this study were blocks consisting of 15 layers requiring 40 minutes to print, whereas the specimen's in Heard's study were 4 layer cylinders. The larger specimen size in this study would contribute to slower cooling and thus a larger microstructure. Additionally, only a 1 minute pause was utilized between print layers in this study whereas 5 minutes per print layer reported in Heard's study. Overall, results from this study were similar to those reported by Heard, allowing for small differences due to differences in experimental set-up. 
Pre-print: Amberlee S. Haselhuhn, Michael W. Buhr, Bas Wijnen, Paul G. Sanders, Joshua M. Pearce, StructureProperty Relationships of Common Aluminum Weld Alloys Utilized as Feedstock for GMAW-based 3-D Metal

Printing. Materials Science and Engineering: A, doi:10.1016/j.msea.2016.07.099 (in press, 2016)

There were no observed differences in the macro solidification structure such as a finer structure near the print outer surface as compared to interior. In castings, the metal solidifies first at the specimen edges and then directionally cools from the outside $\mathrm{in}^{51}$. Thus, the smallest microstructural elements would be found at the specimen edges, yielding to columnar growth inward then to large equiaxed grains in the center of the casting where slower cooling occurred. In welds solidification occurs faster because there is less material deposited at a given time and less heat to extract prior to solidification of the weld. In multi-layer welds, similar to weld-based 3-D printing, the edges of previously welded beads are melted or partially melted which promotes homogenization of the microstructure ${ }^{25,46}$. SDAS on the order of $10 \mu \mathrm{m}$ is common in welding whereas larger dendrite arm spacings on the order of $100 \mu \mathrm{m}$ are more common in casting $^{52}$.

\section{Mechanical Properties}

The average yield strengths and ultimate tensile strength of aluminum containing alloying elements such as silicon and magnesium (4043, 4943, 4047, and 5356) were greater than that of commercially pure 1100 aluminum. All 3-D printed alloys exhibited similar or superior mechanical properties in comparison to standard wrought, weld, or sand cast counterparts (Table 5). Two exceptions to this trend were the lower ductility of 1100 printed specimens and the lower strength of printed 5356 as compared to the wrought material. The 3-D printed aluminumsilicon alloys may have exhibited greater ductility than their cast counterparts due to a smaller microstructure, as described previously. The SDAS of 3-D printed specimens was smaller than average cast SDAS. These smaller dendrites would allow for greater dislocation motion prior to plastic deformation. In general, the fine structure of the printed materials outperformed their sand cast counterparts and approached the performance of wrought-processed material. 
Table 5. Mechanical Properties of Aluminum Alloys from Multiple Processes Compared with Study Results

\begin{tabular}{|c|c|c|c|c|}
\hline Alloy & Process & Tensile Yield (MPa) & UTS (MPa) & Elong. (\%) \\
\hline $1100-\mathrm{O}^{53}$ & Wrought & 34 & 90 & 40 \\
\hline $1100 / 1100^{28}$ & Weld & 31 (min) & 75.8 (min) & 29 \\
\hline 1100 & This Study & $49 \pm 1$ & $92 \pm 6$ & $17 \pm 6$ \\
\hline $443.0(\mathrm{Al}-5.2 \mathrm{Si})^{53}$ & Sand Cast & 55 & 130 & 8 \\
\hline $\mathrm{Al}-5 \mathrm{Si}^{54}$ & Sand Cast & 60 & 125 & 5 \\
\hline $4043(\sim 5.3 \mathrm{Si})$ & This Study & $61 \pm 3$ & $141 \pm 4$ & $17 \pm 3$ \\
\hline $4943(\sim 5.5 \mathrm{Si})$ & This Study & $85 \pm 4$ & $193 \pm 7$ & $15 \pm 2$ \\
\hline $\mathrm{Al}-11.5 \mathrm{Si}^{54}$ & Sand Cast & 65 & 170 & 8 \\
\hline 4047 ( 12 Si) & This Study & $88 \pm 2$ & $180 \pm 4$ & $15 \pm 1$ \\
\hline $5356-\mathrm{O}^{53}$ & Wrought & 130 & 285 & - \\
\hline $514.0(\mathrm{Al}-4 \mathrm{Mg})^{53}$ & Sand Cast & 83 & 172 & 9 \\
\hline $535.0(\mathrm{Al}-6.9 \mathrm{Mg})^{53}$ & Sand Cast & 124 & 250 & 9 \\
\hline 5356 ( 5 Mg) & This Study & $109 \pm 2$ & $230 \pm 10$ & $10 \pm 2$ \\
\hline
\end{tabular}

Compressive yield strength was expected to be higher than in tension. Porosity defects, and particularly non-spherical porosity defects such as interdendritic shrinkage, act as stress concentrators. In tension these defects severely limit material strength whereas in compression they are less detrimental. The decrease in yield strength may also be related to the Peierls stress in aluminum alloys ${ }^{55,56}$. Peierls stress, also known as lattice friction, is the shear stress required to move a dislocation in a given crystal structure. The stress required to move a dislocation increases in compression due to the closer spaced planes and obstacles to dislocation motion. As dislocation pileup occurs, the mobility of dislocations concurrently decreases and more stress 
Pre-print: Amberlee S. Haselhuhn, Michael W. Buhr, Bas Wijnen, Paul G. Sanders, Joshua M. Pearce, StructureProperty Relationships of Common Aluminum Weld Alloys Utilized as Feedstock for GMAW-based 3-D Metal Printing. Materials Science and Engineering: A, doi:10.1016/j.msea.2016.07.099 (in press, 2016)

must be applied to plastically deform a material, resulting in work hardening ${ }^{55}$. There is also more dislocation pileup during compression than in tension, which can be further compounded by alloying additions Error! Bookmark not defined. For instance, magnesium has been observed to increase dislocation multiplication and storage rates, thus increasing work hardening and suppressing recovery in aluminum-magnesium alloys.

An estimate of the strain hardening behavior can be made by subtracting the tensile yield strength from the ultimate tensile strength for each alloy (Figure 19) ${ }^{57}$. As solute concentration increases, the amount of strain hardening also increases. Although there are only slight differences in silicon content between 4043 and 4943, the small magnesium solute concentration in 4943 contributes significantly to the strain hardening response.

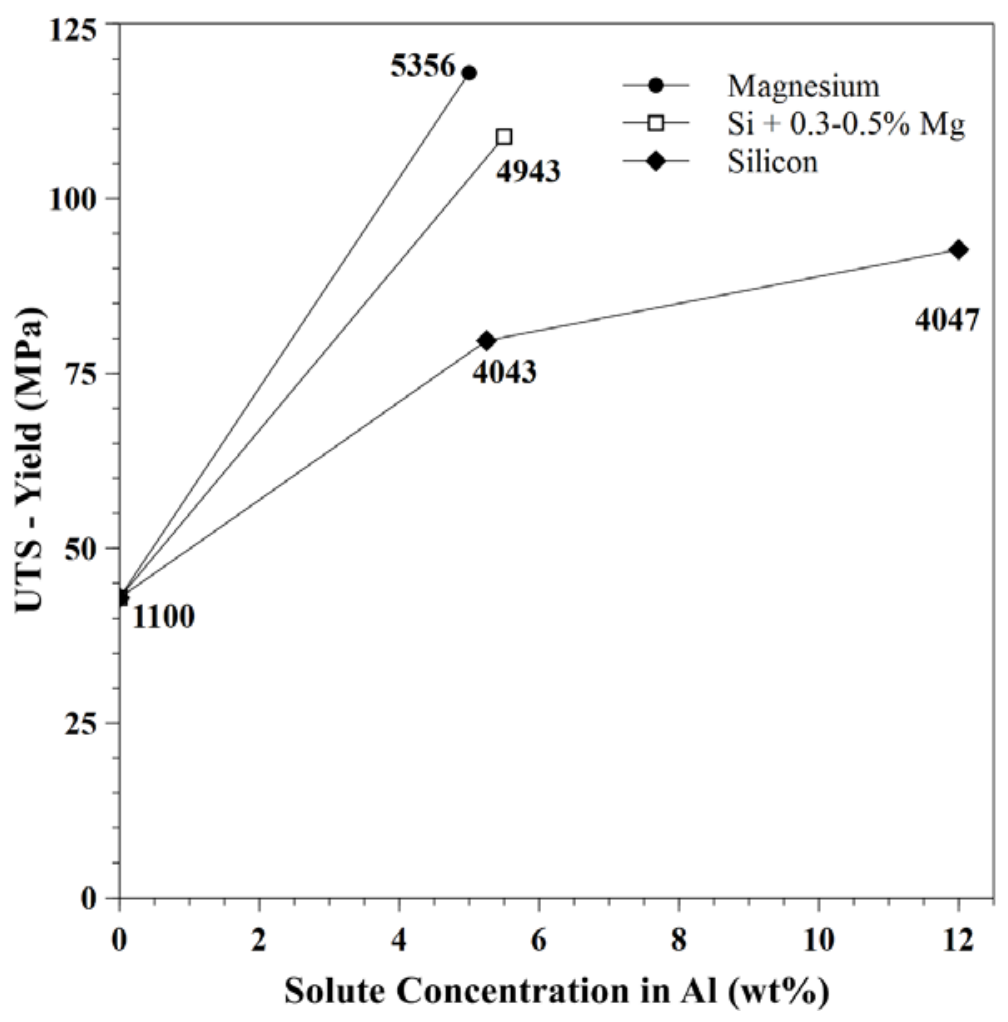


Pre-print: Amberlee S. Haselhuhn, Michael W. Buhr, Bas Wijnen, Paul G. Sanders, Joshua M. Pearce, StructureProperty Relationships of Common Aluminum Weld Alloys Utilized as Feedstock for GMAW-based 3-D Metal Printing. Materials Science and Engineering: A, doi:10.1016/j.msea.2016.07.099 (in press, 2016)

Figure 19. Estimate of the strain hardening response of each aluminum alloy based upon solute content.

In aluminum-silicon alloys, dislocations pile up at silicon phases during plastic deformation because the hard silicon phases cannot be sheared by dislocations. However, Peierls stress may be insufficient to explain the differences observed in yield strength.

Porosity defects can act as stress concentrators causing premature tensile yielding. Interdendritic shrinkage porosity, which is typically elongated and has sharper edges, acts as a greater stress concentrator than spherical gas porosity. Fracture of the tensile specimens occurred in regions of higher than average porosity. Future work is necessary to optimize printer parameters (e.g., welder power, wire feed rate, welding speed, etc.) to minimize defect density. Hydrogen was likely a significant cause of the spherical gas porosity; these defects can be minimized through improved environmental control. Gas porosity defects in 1100 and the combination of gas porosity and interdendritic/intergranular shrinkage defects in 4043, 4943, 4047, and 5356 led to reductions in mechanical properties, particularly elongation.

\section{Conclusions}

A low-cost GMAW-based 3-D metal printer was used to print 1100, 4043, 4943, 4047, and 5356 aluminum parts. The mechanical properties of 3-D printed aluminum alloys were evaluated via tensile and compression tests in conjunction with microstructural analysis. This work was performed in order to optimize process parameters and guide future development of alloys specifically for use with GMAW-based 3-D printing. 
Pre-print: Amberlee S. Haselhuhn, Michael W. Buhr, Bas Wijnen, Paul G. Sanders, Joshua M. Pearce, StructureProperty Relationships of Common Aluminum Weld Alloys Utilized as Feedstock for GMAW-based 3-D Metal Printing. Materials Science and Engineering: A, doi:10.1016/j.msea.2016.07.099 (in press, 2016)

The 4000 series alloys performed better than the other alloys studied when considering porosity and strength. The 1100 specimens exhibited the smallest bead width and lowest porosity, but were also the weakest in tension and compression. The 4000 series alloys exhibited similar bead widths and porosities compared with 1100. Unlike 1100, the 4000 series alloys exhibited significantly higher strengths. The small magnesium additions in 4943 significantly increased its strength over 4043 . While the 5356 specimens were the strongest, they also exhibited the largest bead width and the greatest amount of porosity. These porosity defects likely limited the 5356 test specimens’ strength compared with their wrought counterparts.

These relationships between microstructure and properties can be used by researchers and engineers in the development of new parts, processes, alloys, and technologies for additive manufacturing. Thorough reviews of the structure-property relationships of additively manufactured aluminum are not widely available. However, the properties of 3-D printed aluminum alloys, and particularly 4000 series alloys, evaluated in this study were comparable or superior to those produced via other processes.

\section{Acknowledgments}

The authors wish to acknowledge helpful discussions with Dr. Stephen Kampe, P. Fraley, Z. Boyden, M. Schaub, and M. Yuan, and valuable microscopy and 3-D printing assistance from T. Wood and G. Anzalone, respectively. The authors would also like to acknowledge support and helpful discussions with C. Hsu and technical assistance from the Miller Electric Manufacturing Company. This material is based on research sponsored by Air Force Research Laboratory under agreement number FA8650-12-2-7230. The U.S. Government is authorized to reproduce and distribute reprints for Governmental purposes notwithstanding any copyright notation thereon. 
Pre-print: Amberlee S. Haselhuhn, Michael W. Buhr, Bas Wijnen, Paul G. Sanders, Joshua M. Pearce, StructureProperty Relationships of Common Aluminum Weld Alloys Utilized as Feedstock for GMAW-based 3-D Metal

Printing. Materials Science and Engineering: A, doi:10.1016/j.msea.2016.07.099 (in press, 2016)

The views and conclusions contained herein are those of the authors and should not be interpreted as necessarily representing the official policies or endorsements, either expressed or implied, of Air Force Research Laboratory or the U.S. Government.

\section{Author Disclosure Statement}

No conflicts of interest exist.

\section{References}

${ }^{1}$ Gebhardt, A. Rapid Prototyping. Germany: Hanser Verlag, 2003.

${ }^{2}$ Gershenfeld, N. Fab: The Coming Revolution on Your Desktop - from Personal Computers to Pers. Fabr., New York: Basic Books, 2005.

${ }^{3}$ Wittbrodt, B. T., Glover, A. G., Laureto, J., Anzalone, G. C., Oppliger, D., Irwin, J. L., \& Pearce, J. M. (2013). Life-cycle economic analysis of distributed manufacturing with open-source 3-D printers. Mechatron., 23(6), 713-726.

${ }^{4}$ Birtchnell, T., \& Hoyle, W. (2014). 3D Printing for Development in the Global South: The 3D4D Challenge. Palgrave Macmillan.

${ }^{5}$ Pearce, J. M., Blair, C. M., Laciak, K. J., Andrews, R., Nosrat, A., \& Zelenika-Zovko, I. (2010). 3-D printing of open source appropriate technologies for self-directed sustainable development. J. Sustain. Dev., 3(4), 17-29.

${ }^{6}$ Wohlers, T., \& Caffrey, T. (2014). Wohlers Report 2014 Annual Worldwide Progress Report. Wohlers Associates, Inc. Fort Collins, CO.

${ }^{7}$ Pearce, J. M. (2012). Building research equipment with free, open-source hardware. Science, 337(6100), 1303-1304.

${ }^{8}$ Pearce, J. M. (2013). Open-source lab: How to build your own hardware and reduce research costs. Elsevier: New York.

${ }^{9}$ Sells, E., Smith, Z., Bailard, S., Bowyer, A., \& Olliver, V. (2009). RepRap: The Replicating Rapid Prototyper: Maximizing Customizability by Breeding the Means of Production. in F. T. Piller, M. M. Tseng (Eds.), Handbook of Research in Mass Customization and Personalization: Strategies and concepts. Vol. 1. World Scientific, pp. 568-580, 2010.

${ }^{10}$ Jones, R., Haufe, P., Sells, E., Iravani, P., Olliver, V., Palmer, C., \& Bowyer, A. (2011). RepRap-the replicating rapid prototyper. Robotica, 29(01), 177-191.

${ }^{11}$ Bowyer, A., 2014. 3D Printing and Humanity's First Imperfect Replicator. 3D Printing and Addit. Manuf., 1(1), pp.4-5.

${ }^{12}$ Laeng, J., Stewart, J. G., \& Liou, F. W. (2000). Laser metal forming processes for rapid prototyping - A review. Int. J. Prod. Res., 38(16), 3973-3996. 
${ }^{13}$ Lewis, G. K., \& Schlienger, E. (2000). Practical considerations and capabilities for laser assisted direct metal deposition. Mater. Des., 21(4), 417-423.

${ }^{14}$ Santos, E. C., Shiomi, M., Osakada, K., \& Laoui, T. (2006). Rapid manufacturing of metal components by laser forming. Int. J. Mach. Tools Manuf., 46 (12-13), 1459-1468.

${ }^{15}$ Delgado, J., Ciurana, J., \& Serenó, L. (2011). Comparison of forming manufacturing processes and selective laser melting technology based on the mechanical properties of products. Virtual Phys. Prototyp., 6(3), 167-178.

${ }^{16}$ Heinl, P., Rottmair, A., Körner, C., \& Singer, R. F. (2007). Cellular titanium by selective electron beam melting. Adv. Eng. Mater., 9(5), 360-364.

${ }^{17}$ Gaytan, S. M., Murr, L. E., Medina, F., Martinez, E., Lopez, M. I., \& Wicker, R. B. (2009). Advanced metal powder based manufacturing of complex components by electron beam melting. Mater. Tech., 24(3), 180-190.

${ }^{18}$ Murr, L. E., Gaytan, S. M., Ramirez, D. A., Marinez, E., Hernandez, J., Amato, K. N., Shindo, P. W., Medina, F. R., \& Wicker, R. B. (2012). Metal fabrication by additive manufacturing using laser and electron beam melting technologies. J. Mater. Sci. Tech., 28(1), 1-14.

${ }^{19}$ Peels, J. (23 May 2014). Metal 3D printing: From lab to fab. Inside 3DP. Retrieved from http://www.inside3dp.com/metal-3d-pinting-lab-fab/.

${ }^{20}$ Ribeiro, F. 3D printing with metals, Comput. Control Eng. J., Vol. 9, no. 1, pp. 31-38, 1998.

${ }^{21}$ Anzalone G. C., Zhang C., Wijnen B., Sanders, P. G., Pearce, J. M. (2013). A low-cost opensource metal 3-D printer. IEEE Access, 1, 803-810.

${ }^{22}$ Haselhuhn, A. S., Gooding, E. J., Glover, A. G., Anzalone, G. C., Wijnen, B., Sanders, P. G., \& Pearce, J. M. (2014). Substrate release mechanisms for gas metal arc weld 3-D aluminum metal printing. 3-D Print. Addit. Manuf., 1(4), 204-209.

${ }^{23}$ Haselhuhn, A. S., Wijnen, B., Anzalone, G.C., Sanders, P.G., \& Pearce, J.M. (2015). In situ formation of substrate release mechanisms for gas metal arc weld metal 3-D printing. $J$. Mater. Process. Tech., 226, 50-59.

${ }^{24}$ Easterling, K. Introduction to the physical metallurgy of welding; 1983. London, Butterworth.

${ }^{25}$ Lancaster, J. F. Metallurgy of Welding; 1993. London, Chapman \& Hall.

${ }^{26}$ Zhao, H., Zhang, G., Yin, Z., \& Wu, L. (2011). A 3D dynamic analysis of thermal behavior during single-pass multi-layer weld-based rapid prototyping. J. Mater. Process. Tech., 211(3), 488-495.

${ }^{27}$ Zhao, H., Zhang, G., Yin, Z., \& Wu, L. (2012). Three-dimensional finite element analysis of thermal stress in single-pass multi-layer weld-based rapid prototyping. J. Mater. Process. Tech., 212(1), 276-285.

${ }^{28}$ Dickerson, P. B. (1993). Welding of Aluminum Alloys. ASM Handbook, 6, 722-739.

${ }^{29}$ Anderson, B.E. (2011). U.S. Patent Application No. 13/023,158. Publication No. 2011/0194973 (Published August 11, 2011). Washington, DC: U.S. Patent and Trademark Office.

${ }^{30}$ Martukanitz, R. P. (1993). Selection and Weldability of Heat-Treatable Aluminum Alloys. ASM Handbook, 6, 528-536.

${ }^{31}$ Heard, D. W., Brophy, S., \& Brochu, M. (2012). Solid freeform fabrication of Al-Si components via the CSC-MIG process. Can. Metall. Q., 51(3), 302-312.

${ }^{32}$ Nilsiam, Y., Haselhuhn, A., Wijnen, B., Sanders, P. and Pearce, J.M., 2015. Integrated voltagecurrent monitoring and control of gas metal arc weld magnetic ball-jointed open source 3-D printer. Mach., 3(4), pp.339-351. 
${ }^{33}$ Wijnen, Bas. MTU-MOST Franklin, https:/github.com/mtu-most/franklin, last accessed February 9, 2015.

${ }^{34}$ Pinar, A. Wijnen, B., Anzalone, G.C., Havens, T.C., Sanders, P.G., \& Pearce, J.M. (2015). Low-Cost Open-Source voltage and current monitor for gas metal arc weld 3-D printing. J. Sens., 2015: 8.

${ }^{35}$ AlcoTec Wire Corporation. Alloy 1100 weld data sheet. http://www.alcotec.com/us/en/ support/upload/a1100tds.pdf, last accessed February 3, 2016.

${ }^{36}$ Hobart Brothers Company. Hobart MAXAL 4043. http://maxal.com/Hobart_Maxal_4043.pdf, last accessed 3 February 2016.

${ }^{37}$ Hobart Brothers Company. Hobart MAXAL 4943. http://maxal.com/Hobart_Maxal_4943.pdf, last accessed 3 February 2016.

${ }^{38}$ AlcoTec Wire Corporation. Aloy 4047 weld data sheet. http:/www.alcotec.com/us/en/ support/upload/a4047tds.pdf, last accessed 3 February 2016.

${ }^{39}$ Hobart Brothers Company. Hobart MAXAL 5356. http://maxal.com/Hobart_Maxal_5356.pdf, last accessed 3 February 2016.

${ }^{40}$ ASTM B557-02. Standard Test Methods for Tension Testing Wrought and Cast Aluminumand Magnesium-Alloy Products. ASTM International, West Conshohocken, PA, 2013, www.astm.org.

${ }^{41}$ Meyers, M, \& Chawla, K. (2009). Mechanical Behavior of Materials. $2^{\text {nd }}$ Ed. Cambridge: Cambridge University Press.

${ }^{42}$ Rasband, W. S., Image J., U.S. National Institutes of Health, Bethsesda, Maryland, USA, http://imagej.nih.gov/ig/, 1997-2014.

${ }^{43}$ Bouchard, D., \& Kirkaldy, J. S. (1997). Prediction of dendrite arm spacings in unsteady- and steady-state heat flow of unidirectionally solidified binary alloys. Metall. Mater. Trans. $B, 28(4), 651-663$.

${ }^{44}$ Su, S., Liang, X., Moran, A., \& Lavernia, E. J. (1994). Solidification behavior of an Al-6Si alloy during spray atomization and deposition. Int. J. Rapid Solidif., 8(3), 161-177.

${ }^{45}$ Hatch, J.E. Aluminum Properties and Physical Metallurgy. 1984. Metals Park, Ohio: American Society for Metals.

${ }^{46}$ Kou, S. (1987). Welding Metallurgy. New York: John Wiley \& Sons.

${ }^{47}$ Magnusson, T., \& Arnberg, L. (2001). Density and solidification shrinkage of hypoeutectic aluminum-silicon alloys. Metall. Mater. Trans. A, 32(10), 2605-2613.

${ }^{48}$ Porter, D.A., Easterling, K.E., \& Sherif, M.Y. Phase Transformations in Metals and Alloys. $3^{\text {rd }}$ Edition. 2009. Boca Raton, FL, CRC Press.

${ }^{49}$ Hirano, K., Agarwala, R. P., \& Cohen, M. (1962). Diffusion of iron, nickel, and cobalt in aluminum. Acta Metall., 10(9), 857-863.

${ }^{50} \mathrm{Lu}, \mathrm{L} .$, \& Dahle, A. K. (2005). Iron-rich intermetallic phases and their role in casting defect formation in hypoeutectic Al-Si alloys. Metall. Mater. Trans. A, 36(13), 819-835.

${ }^{51}$ Campbell, F. C. (Ed.). (2008). Elements of Metallurgy and Engineering Alloys, ASM International, Materials Park, $\mathrm{OH}, 487-508$.

${ }^{52}$ Cross, C.E., Olson, D.L., \& Liu, S. (2003). Aluminum Welding. In G.E. Totten \& D.S. MacKenzie (Eds.), Handbook of Aluminum Volume 1 (481-532). New York: Marcel Dekker, Inc.

${ }^{53}$ Kaufman, J. G. (Ed.). (1999). Properties of aluminum alloys: Tensile, creep, and fatigue data at high and low temperatures. ASM International. 
${ }^{54}$ Gale W. F., \& Totemeier, T. C. (Eds.). Smithells metals reference book, $8^{\text {th }}$ Ed., ButterworthHeinemann, 2003, 14-16.

${ }^{55}$ Hertzberg, R.W., Vinci, R.P., \& Hertzberg, J.L. (2012). Deformation and Fracture Mechanics of Engineering Materials. $5^{\text {th }}$ Ed. New York: John Wiley \& Sons.

${ }^{56}$ Shin, I. \& Carter, E.A. (2013). Possible origin of the discrepancy of Peierls stresses of fcc metals: First-principles of dislocation mobility in aluminum. Phys. Rev. B, 88 (6), 1-10.

${ }^{57}$ Tiryakioglu, M., \& Staley, J.T. (2003). Physical Metallurgy and the Effect of Alloying Additions in Aluminum Alloys. In G.E. Totten \& D.S. MacKenzie (Eds.), Handbook of Aluminum Volume 1 (81-209). New York: Marcel Dekker, Inc. 